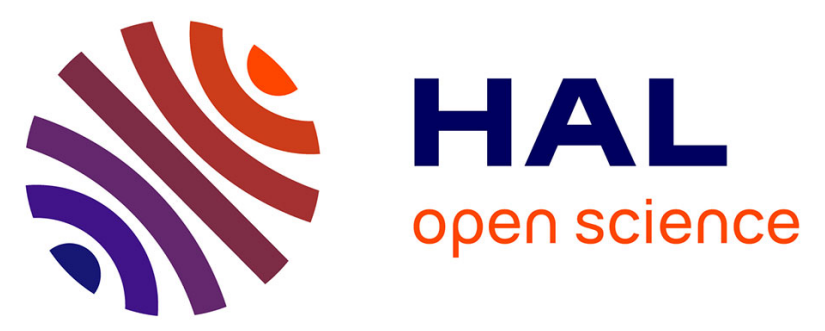

\title{
Soft-bottom macrozoobenthos in semi-enclosed coastal systems of Morocco: A latitudinal and biogeographic analysis
}

Soilam Boutoumit, Reda El Kamcha, Oussama Bououarour, Latifa Joulami, Loubna Boutahar, Abdelaziz Benhoussa, Mohamed Maanan, L. Godet, Abdellatif Bayed, Hocein Bazairi

\section{To cite this version:}

Soilam Boutoumit, Reda El Kamcha, Oussama Bououarour, Latifa Joulami, Loubna Boutahar, et al.. Soft-bottom macrozoobenthos in semi-enclosed coastal systems of Morocco: A latitudinal and biogeographic analysis. Regional Studies in Marine Science, 2021, 44, pp.101689. 10.1016/j.rsma.2021.101689 . hal-03467914

\section{HAL Id: hal-03467914 https://hal.science/hal-03467914}

Submitted on 6 Dec 2021

HAL is a multi-disciplinary open access archive for the deposit and dissemination of scientific research documents, whether they are published or not. The documents may come from teaching and research institutions in France or abroad, or from public or private research centers.
L'archive ouverte pluridisciplinaire HAL, est destinée au dépôt et à la diffusion de documents scientifiques de niveau recherche, publiés ou non, émanant des établissements d'enseignement et de recherche français ou étrangers, des laboratoires publics ou privés. 


\section{Journal Pre-proof}

Soft-bottom macrozoobenthos in semi-enclosed coastal systems of Morocco: A latitudinal and biogeographic analysis

Soilam Boutoumit, Reda El Kamcha, Oussama Bououraour, Latifa Joulami, Loubna Boutahar, Abdelaziz Benhoussa, Mohamed Maanan, Laurent Godet, Abdellatif Bayed, Hocein Bazairi

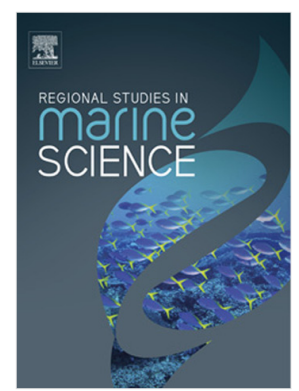

PII:

S2352-4855(21)00081-5

DOI: $\quad$ https://doi.org/10.1016/j.rsma.2021.101689

Reference: RSMA 101689

To appear in: Regional Studies in Marine Science

Received date: 6 August 2020

Revised date: 13 November 2020

Accepted date : 20 February 2021

Please cite this article as: S. Boutoumit, R. El Kamcha, O. Bououraour et al., Soft-bottom macrozoobenthos in semi-enclosed coastal systems of Morocco: A latitudinal and biogeographic analysis. Regional Studies in Marine Science (2021), doi: https://doi.org/10.1016/j.rsma.2021.101689.

This is a PDF file of an article that has undergone enhancements after acceptance, such as the addition of a cover page and metadata, and formatting for readability, but it is not yet the definitive version of record. This version will undergo additional copyediting, typesetting and review before it is published in its final form, but we are providing this version to give early visibility of the article. Please note that, during the production process, errors may be discovered which could affect the content, and all legal disclaimers that apply to the journal pertain.

(C) 2021 Elsevier B.V. All rights reserved. 

and biogeographic analysis

3 Soilam Boutoumit ${ }^{\mathrm{a},}$ b, Reda El Kamcha ${ }^{\mathrm{a}}$, Oussama Bououraour ${ }^{\mathrm{a}}$, Latifa Joulamic ${ }^{\mathrm{c}}$, Loubna

4 Boutahar $^{\mathrm{a}, \mathrm{d}}$, Abdelaziz Benhoussa ${ }^{\mathrm{a}}$, Mohamed Maanan ${ }^{\mathrm{b}}$, Laurent Godet ${ }^{\mathrm{e}}$, Abdellatif Bayed ${ }^{\mathrm{f}}$, 5 Hocein Bazairi ${ }^{a^{*}}$

6 a BioBio Research Center, BioEcoGen Laboratory, Faculty of Sciences, Mohammed V University 7 in Rabat, 4 Avenue Ibn Battouta, B.P. 1014 RP, 10106, Rabat, Morocco

8 b Université de Nantes. UMR 6554 LETG-Nantes, BP 81227, F-44312 Nantes Cedex 03, France

$9{ }^{\mathrm{c}}$ Laboratoire d'Ecologie et Environnement, Faculté des Sciences Ben M'sik, B.P. 7955, Sidi

10 Othman-Casablanca, Morocco

11 d Laboratorio de Biología Marina, Departamento de Zoología, Universidad de Sevilla, Avda.

12 Reina Mercedes 6, 41012, Sevilla, Spain

$13{ }^{\mathrm{e}}$ CNRS. UMR LETG-Nantes, Université de Nantes, BP 81227, F-44312 Nantes Cedex 03, France

$14{ }^{\mathrm{f}}$ Institut Scientifique, Unité de Recherche OCEMAR, Mohammed V University in Rabat, 4 Avenue 15 Ibn Battouta, B.P. 703 RP, 10106, Rabat, Morocco

16

*Corresponding author. E-mail address: hocein.bazairi@um5.ac.ma (H.Bazairi) 


\section{ABSTRACT}

Although soft-bottoms are the largest ecosystem on Earth in terms of area, only a small percentage of their macrobenthos has been studied and most of its species are not yet described. Herein, the most up-to-dated comprehensive inventory and the broad-scale baseline of the soft-sediment macrozoobenthos in semi-enclosed coastal systems (SECS) of the Moroccan Atlantic and Mediterranean coasts $(3500 \mathrm{~km})$ is presented. In total, 496 species (7 phyla, 21 classes, 65 orders and 201 families) were recorded among which 95 species were exlusively Mediterranean, 99 species were Atlantico-Mediterranean SECS and 302 species exclusively Atlantic.

The best multivariate model, explaining $33 \%$ of the total variation observed in benthic assemblages' composition, included the type of the SECS (estuaries vs lagoons vs bay), the marine ecoregion (Atlantic vs Mediterranean), the surface of the SECS and the environmental features (minimal temperature, minimal and maximal salinity) as predictors of benthic macrofauna composition in the Moroccan SECS. In contrast to the general latitudinal diversity gradient (LDG) pattern, our results showed that species richness and taxonomic diversity showed no relationship with latitude. Such differences in benthic macrofaunal composition across a large scale could result from the fact that each ecosystem has its own specific characteristics, which implies an individualistic approach to ecosystem ecology.

The sample of the 12 SECS considered in this study covers most of the range of variation along the coasts of Morocco. The current compilation is relevant in such poorly known area at the global scale and fulfills a knowledge gap on benthic macrofauna in SECS of the Southern part of the North-Eastern Atlantic and Mediterranean ecoregions. However, the knowledge gained here is insufficient to address perceived shortfalls in knowledge of biodiversity, its importance to ecosystem function, and the threats and consequences of disturbance by anthropogenic activities.

Key words: Benthic macrofauna; Checklist; Latitudinal diversity gradient; North-East Atlantic; Mediterranean. 


\section{Introduction}

Ecologists have long been intrigued by global patterns in biodiversity (Piacenza et al., 2015) and the understanding of the distribution of life on earth is a main goal in ecology and biogeography (Gaston, 2000; Hillebrand, 2004). The latitudinal diversity gradient, hereafter LDG (Hawkins, 2001), with the highest numbers of species in the tropics and gradual decrease poleward, is the most famous large-sclae biodiversity pattern (Hillebrand, 2004; Kinlock et al., 2018). Explanations for the LDG have been related to many potential mechanisms but no broad consensus on the causes of the LDG has emerged (Kinlock et al., 2018). The many explanations that have been proposed can be categorized broadly into ecological, evolutionary and historical processes (see Cruz-Motta et al., 2020 for recent summaries). Given the challenge of inferring process from pattern, disentangling these hypothesized drivers remains one of the great challenges in macroecology (Hurlbert \& Stegen, 2014).

While the LDG is a well-recognized and long-established pattern in terrestrial ecology, the knowledge of global diversity patterns in marine ecosystems is limited to a small number of studies (Barboza \& Defeo, 2015). For marine biota, the first suggestion of the latitudinal diversity cline was formulated in late $1950^{\text {ies }}$ for hard bottom epifauna (Thorson, 1957) with pronounced decrease in the species richness of hard substratum epifauna towards arctic areas, whereas the number of soft-sediment infauna species was roughly the same in tropical, temperate and arctic areas. Latitudinal clines in benthic diversity of shallow waters have been also reported for gastropods (Roy et al. 1998), bivalve molluscs (Crame 2000; Roy, Jablonski \& Valentine 2000), in shallow and deep-seas benthos (Sanders, 1968; Poore \& Wilson 1993; Rex et al. 1993), and for pelagic taxa (Angel 1997; Pierrot-Bults 1997). Nevertheless, many studies have shown a deviation from the general LDG for the shallow-water marine fauna (Kendall \& Aschan 1993; Boucher \& Lambshead 1995). Furthermore, in the southern hemisphere the evidence of a latitudinal gradient of decreasing richness from the tropics to Antarctica is less convincing than in the northern hemisphere (Clarke 1992; Poore \& Wilson 1993; Crame 2000). Recently, Kinlock et al. (2018) revisited the challenge of synthesizing individual LDGs and indicated that the phenomenon is not ubiquitous among habitats of the marine realm. More precisely, they indicated that the phenomenon is non-significant in the benthic habitat. However, Menegotto et al. (2019), in their comment on Kinlock et al. (2018), suggest that the marine habitat categories used by them (i.e., 
benthic, coral reefs, coastal, open ocean) are not independent and that reclassifying the studies significantly alters one of their main results. By assigning the studies into benthic and pelagic categories, and additionally into coastal or oceanic zones, they show that non-ambiguous, evolutionarily meaningful marine habitats display a significant latitudinal decline in species richness. Thus, there is no convincing evidence of a latitudinal cline across all taxa in the sea comparable to that seen on land (Clarke 1992; Clarke \& Crame 1997).

Meta-analysis represents a suitable technique to analyse latitudinal gradients across different biota and regions and thus to generalize or not findings on the latitudinal distribution of species richness (Hillbrand, 2004; Kinlock et al., 2019). Therefore, Open science and the accumulation of spatially explicit biodiversity data are crucial to document LDG patterns better and to evaluate hypotheses broadly or for particular groups of organisms (Kinlock et al., 2018; 2019).

Soft-bottom substrates cover most of the world's ocean bottom and maintain a substantial part of the world's biodiversity (Snelgrove, 1998; Labrune et al., 2008). Assessing their biodiversity and latitudinal patterns, even though it is complicated by the difficulty in sampling and sharply delineating habitats in these systems, is thus of special importance (Labrune et al., 2008). Macrobenthos constitute the dominant organism biomass of marine soft sediments (Snelgrove, 1998). All of the known non-symbiont phyla but one are found in the marine environment, with most being represented in marine sediments (Grassle et al., 1991). Soft bottom macrobenthos is a key biological component of marine ecosystems where it plays an important role in ecological processes such as nutrient cycling, pollutant metabolism or secondary production (Snelgrove, 1998; Pratt et al., 2014). Although soft-bottoms are the largest ecosystem on Earth in terms of area, only a small percentage of their macrobenthos has been studied and most of its species are not yet described (Snelgrove, 1998). In this way, it is useful to improve our knowledge of its biodiversity (Ellingsen, 2002; Veiga et al., 2016).

Semi-enclosed coastal systems (SECS), such as lagoons and estuaries, are particular ecosystems of the coastal zone where the macrobenthos is a dominant biological component. The SECS are largely distributed worldwide under all the latitudes and are therefore ideal systems to study LDGs and their potential drivers because they (a) are easily accessible and (b) have very diverse, abundant, macrobenthic organisms belonging to various taxonomic groups. 
The Moroccan coast stretches over $3500 \mathrm{~km}$ and $15^{\circ}$ of latitude along both the Mediterranean Sea and the Atlantic Ocean. Moroccan low coasts offer an important succession of particular geomorphological forms (Chafik et al., 2001) among which several lagoons, estuaries and bays. Nador and Smir lagoons lie on the Mediterranean coast, whereas Moulay Bousselham, Sidi Moussa, Oualidia and Khnifiss are located in the Atlantic coast. The largest estuaries are located in the Atlantic coast: Tahaddart, Loukkos, Sebou, Bouregreg and Oum Rbia. Finally, Dakhla bay is the most important bay of the Atlantic coast of Morocco, it is unique in North Africa as a migration, wintering and nesting area for thousands of waterbirds (Qninba et al., 2003). Those ecosystems are heterogeneous, mainly due to their typology (bay, estuaries, lagoons), geomorphology, catchment geology and the spatio-latitudinal variation in different environmental factors along the Moroccan coasts

Up-to-now, there is no synthesis of the benthic species of the Moroccan SECS, despite several studies conducted in the last decades (e.g. Elkaïm, 1974; Lacoste, 1984; Bekkali, 1987; Guelorget et al., 1987; Bayed et al., 1988; Cheggour, 1988; Zine, 1989; Chbicheb, 1996; Bazairi, 1999; Mergaoui, et al., 2003; Chaouti and Bayed, 2005; Zine, 2005; Azirar, 2006; Cherkaoui, 2006; Gauteur, 2006; Lefrere, 2012; Joulami, 2013; Bazairi et al., 2014; Boutahar, 2014; El Asri et al., 2015; El Asri et al., 2017; Touhami, 2018; El Asri, 2019). This was a stimulating fact to provide a first baseline meta-data on such ecosystems in such poorly known area at the global scale and to fulfill a knowledge gap on benthic macrofauna in SECS of the Southern North-East Atlantic and Mediterranean ecoregions.

The overall objectives of this study were (1) to provide the first national and comprehensive checklist of the soft bottom macrozoobenthic species in semi-enclosed coastal systems of Morocco, (2) to test for the presence of a latitudinal diversity gradients in soft bottom macrozoobenthic species of semi-enclosed coastal systems of Morocco and (3) to understand their drivers by comparing the benthic assemblages between the different sites according to their ecoregion, their latitudinal position, the type of ecosystem (lagoon, estuary or bay), the site surface area, temperature and salinity. Additionally, we identified the current knowledge and gaps and make recommendations on respective research in future years. 
14012 SECS were considered in this study based of data availability (Fig. 1). There are distributed 141 along a large latitudinal gradient and are situated both in the Mediterranean coast of Morocco (two 142 lagoons) and the Atlantic coast of Morocco (four lagoons, five estuaries and one bay). These SECS 143 differ in terms of configuration, surface area and environmental conditions (Table 1). These sites 144 have a very important ecological interest; most of them have been listed to the RAMSAR 145 Convention as wetlands of international importance. They represent the most important Moroccan 146 wetlands for the migration and wintering of birds.

147 These SECS are contrasting in the climate: Mediterranean semi-arid to temperate variant at the 148 level of Nador lagoon to a desert climate at Dakhla bay. On the other hand, anthropogenic activities 149 differ from one site to another: traditional fishing (all sites), aquaculture (Oualidia and Dakhla), 150 thermal power station (Tahaddart), intensive agriculture (Moulay Bousselham, Sidi Moussa and 151 Oualidia), port's activities (Nador, Loukkos, Sebou, Bouregreg, and Dakhla), dredging activities 152 (Sebou and Oum Rbia,), mining (Nador, Sidi Moussa, Oualidia and Khnifiss) and industrial 153 effluents (Nador, Sidi Moussa and Dakhla).

The checklist was based on published data from 1974 to 2020 as well as co-authors unpublished data (see Table S1 and Table 4 for references' details). The list of benthic macrofauna species and total species richness were compiled for each SECS. Species names were checked and updated to current nomenclature according to World Register of Marine Species

159 (http://www.marinespecies.org) (consulted January 14, 2020). Only few species were not included

160 in WORMS. Taxa identified at a higher taxonomic level than the species were removed from the 161 checklist. Only the taxa sp. and cf. were retained if cited only once.

162 The heterogeneity and incompleteness of available information led to the selection of a subset of 163 the SECS environment descriptors which fulfilled the criteria of data reliability (i.e. information 164 coming from published sources), homogeneity (i.e. available for all the lagoons), and comparability (i.e. data which can be expressed with a shared measurement unit). Nine different SECS variables were included: type of aquatic system ( 1 = lagoon; 2 = estuary; 3 = bay), latitude 
167 (LAT), longitude (LON), surface area, maximum annual water temperature $\left(\mathrm{M} \mathrm{Temp},{ }^{\circ} \mathrm{C}\right)$, 168 minimum annual water temperature (m Temp, $\left.{ }^{\circ} \mathrm{C}\right)$, maximum annual water salinity (M Sal), 169 minimum annual water salinity (m Sal).

Biotic parameters including the species richness (S), average taxonomic distinctness with presence/absence data $\left(\Delta^{+}\right)$, total taxonomic distinctness $\left(\mathrm{S} \Delta^{+}\right)$, average phylogenetic diversity $(\Phi+)$ and variation in taxonomic distinctness $(\Lambda+)$, total phylogenetic diversity $(\mathrm{S} \Phi+)$ were calculated.

Sampling effort leading to the compilation of the species lists was also measured by the total number of samples collected in each SECS (calculated as number of sampling sites x sampling frequency).

\subsection{Data analysis}

179 The relation between SECS characteristics (independent variables) on species richness and taxonomic diversity indices (dependent variables) was tested using multiple linear regressions after testing the collinearity between independent variables. The possible effect of sampling effort on biotic parameters was previously tested by univariate regression. Then, residuals of the univariate regression with sampling effort were considered instead of the original data in multiple regression analysis. Moreover, the effect of the types of SECS (lagoon vs estuary) was tested using univariate PERMANOVA (Anderson et al., 2004).

Differences in the structure of the taxonomic assemblages between Moroccan SECS were explored using a cluster analysis based on a Bray-Curtis coefficient. Similarities (Bray-Curtis coefficient) among Moroccan SECS were calculated based on the taxonomical composition (Bray-Curtis coefficient calculated on $(0,1)$ species presence-absence data corresponding to Sorensen coefficient (Clarke and Warwick, 2001) (Table S2). Affinity groups differences were visualized

191 through Principal Coordinates Ordination analysis (PCO) (Clarke and Warwick, 2001). The abiotic

192 variables that were correlated (Spearman $\rho>0.5$ ) to samples ordination were represented as superimposed vectors in the PCO graph. 
194

195

196

197

198

199

200

201

202

203

204

205

206

207

208

209

210

211

212

213

214

215

216

217

The best subset of SECS characteristics explaining the observed variability in benthic macrofauna assemblages was selected by means of distance-based linear models (DISTLM) (Anderson et al., 2008), using appropriate permutation (9999 permutations) and with Adjusted $\mathrm{R}^{2}$ criterion and stepwise procedure for the model selection. Distances among aquatic systems were visualized through a dbRDA plot. Predictors variables were partitioned to four sets of predictor variables: environmental variables (surface area, maximum annual water temperature (minimum annual water temperature, maximum annual water salinity, minimum annual water salinity), type of SECS (lagoon, estuary, bay), province (Mediterranean and Atlantic) and geographical variables (latitude and longitude).

All multivariate analyses were conducted in the Primer 7 space (Clarke and Gorley, 2006), while correlation and regressions tests were carried out in Statistica 12.0 (Statsoft, 2017).

\section{Results}

\subsection{Checklist}

36 sets of both published and unpublished data were compiled to obtain the checklist of benthic macrofauna of SECS of Morocco (Table S1). Most of them focused on a single SECS. There were 496 species recorded from the Moroccan SECS. They belong to 7 phyla, 21 classes, 65 orders and 201 families. Molluscs are the richest phylum with 179 species belonging to 5 classes, 31 orders and 71 families. Arthropods is the second richest phylum with 164 species belonging to 5 classes, 12 orders and 72 families. 120 species of Annelida were reported, with 2 classes, 7 orders and 33 families. Chordata presented 15 species, from 1 class, 5 orders and 9 families. The phylum of Echinodermata, Cnidaria, and Nemertea were represented by 8, 6 and 4 species respectively.

Among the 496 species reported in this study, 95 species showed an exclusive Mediterranean distribution (M), 99 species have an Atlantico-Mediterranean distribution (AM) and 302 have an Atlantic distribution (A) (Fig. 2).

\subsection{Species composition and taxonomic diversity}

Values estimated for the different indices are summarised in Table 2. The number of taxa compiled by site fluctuated between 32 (Loukkos estuary) and the 161 (Moulay Bousselham lagoon) (Table 
3). Sampling effort showed a wide variability among the studied sites, with the maximal value in Moulay Bousselham lagoon and the minimum in Loukkos estuary (Table 4). With the exception of average phylogenetic diversity $(\Phi+)$ and variation in taxonomic distinctness $(\Lambda+)$, all the other indices showed significant dependence with the sampling effort $(p<0.05)$. Moreover, all the taxonomic indices were significantly $(\mathrm{p}<0.05)$ related to species richness except the average taxonomic distinctness $\left(\Delta^{+}\right)$. In the majority of the SECS, both average taxonomic distinctness

$227\left(\Delta^{+}\right)$and variation in taxonomic distinctness $\left(\Lambda^{+}\right)$were within the $95 \%$ confidence funnel $228(\mathrm{p} \geq 0.05)$. Only the Oum Rbia and the Sebou estuaries as well as the Khnifiss lagoon appeared out 229 of the confidence funnels (Fig. 3).

230 Multiple regression analysis $(\mathrm{p}>0.05)$ revealed that none of the SECS features considered here are 231 structural abiotic features regarding the species richness and the taxonomic diversity indices. 232 Moreover, permutational multivariate analysis of variance (PERMANOVA) showed no 233 interactions between type of SECS ( $p>0.05)$ (Table 3$)$ in terms of species richness (S) and all 234 taxonomic diversity indices (Table 4).

\subsection{Macrobenthic assemblages' affinity}

236 Cluster analysis, at a similarity distance of 40\%, allowed to distinguish three affinity groups (Fig. 237 4): G1 (40\% of similarity) composed by Bouregreg estuary and Moulay Bousselham lagoon, G2 238 (50\% of similarity) composed by Tahaddart, Loukkos and Oum Rbia estuaries and G3 (60\% of 239 similarity) composed by Oualidia and Sidi Moussa lagoons; the others SECS (Nador and Smir 240 lagoons on the Mediterranean coast; Khnifiss lagoon and Dakhla bay on the Atlantic coast) remain 241 individually separated from the previous groups with similarity fluctuating between $20 \%$ and $30 \%$.

242 The obtained affinity groups as well as the other sites were represented on the PCO ordination 243 graph (Fig. 5). The first two ordination axes explained 36\% (all sites considered) of the total 244 variance in benthic macrofauna assemblages. The two-dimensional plots show a clear separation 245 between lagoons and estuaries systems.

246 Through the DistLM analysis, only the SECS-type set of predictor variables had a significant relationship (type-estuary and type-lagoon) with species-derived multivariate cloud $(\mathrm{p}<0.01)$, explaining $27 \%$ of the total variation. However, the best model obtained through the DistLM 
249

250

251

252

253

254

255

256

procedure included height variables (Type-estuary, Type-lagoon, Type-bay, Province-Atlantic Surface, $\mathrm{m}$-Temp, $\mathrm{m}$-Sal and M-Sal) as predictors of benthic macrofauna composition, explaining $33 \%$ of the total variation (Adjusted $\mathrm{R}^{2}=0.33$ ). When transposed to the dbRDA plot, the first two axes captured nearly $62 \%$ of the variability in the fitted model and $47 \%$ of the total variation in the data cloud (Fig. 6). Axis 1 (representing $20 \%$ of total variation) was negatively correlated to Typeestuary $(r=-0.58)$ and to M-Sal $(r=-0.52)$. Axis 2 (representing $14 \%$ of total variation) was negatively correlated to Surface $(\mathrm{r}=-0.53)$. The axis 3 (representing $13 \%$ of total variation) was negatively correlated to Province-Atl $(r=-0.52)$ and Type-bay $(r=-0.55)$.

\subsection{Gaps and knowledge gained}

Table 4 showed that there is a scarcity of studies and that there is no regular spatio-temporal monitoring. Sampling techniques, effort and objectives differ between sites and studies. Although all the existing studies are quantitative, most of them were single spot studies, had limited geographic scope (Mergaoui et al., 2003; Ait Mlik, 2009; Bououarour, 2013; Joulami, 2013), focused only on single taxonomic groups (e.g. Annelida: El asri et al., 2017; Arthropoda: Aksissou, 1997; Boussalwa et al., 2000), or on habitats (intertidal, subtidal, meadows). On the other hand, few studies have been carried out on benthos-predator interactions (Joulami, 2013; Touhami et al., 2019). Moreover, while few studies have considered biomass, there is no evaluation of secondary production and productivity in all the Moroccan SECS. As a result, the studies that can be considered as references for soft sediments benthic assemblages are those of Guelorget et al. (1987), Zine (1989) and El Kamcha (unpublished data) for the lagoon of Nador, Bazairi \& Gam (2004) for the Loukkos estuary, Bazairi (1999) and Boutoumit (unpublished data) for the Moulay Bousselham lagoon, Elkaïm (1974) and Cherkaoui (2006) for the Bouregreg estuary, Gauteur (2006), Boutahar (2014) and El asri (2019) for the Oualidia lagoon, Bazairi \& Zourarah (2001, 2007) and Bazairi et al. (2017) for the Oum Rbia estuary and finally El asri (2019) for Dakhla bay.

\section{Discussion}

Checklists of marine species at regional scale have multiple uses. In addition to offering comparative facts for biodiversity studies, they serve as a crucial device in spotting and delimiting regions in need of protection, inferring the capacity effect of anthropogenic interest, assessing the 
complexity of organic communities, and estimating the provision of dwelling resources (Hendrickx and Harvey, 1999).

The sample of SECS considered in this study covers most of the range of variation along the coasts of Morocco. Therefore, the current compilation represents the first comprehensive annotated checklist that gives an overall view on soft-bottom benthic macrofauna of the semi-enclosed coastal systems within the Atlantic and Mediterranean oceanographic regions of Moroccan waters, which is relevant in such poorly known area at the global scale. Moreover, it fulfilled a knowledge gap on benthic macrofauna in SECS of the Southern part of the Northeastern Atlantic and Mediterranean ecoregions. While all the existing inventories on Moroccan marine fauna focused on single taxonomic group and have large scope, our ecosystem-based checklist is more than a simple list of species inhabiting comparable ecosystems and constitutes a synthetic illustration of the relationships that species have with each other and with their environment. Furthermore, the resulting metadata, available in open acces, will serve in comparing the soft-bottom macrobenthos assemblages at a large scale.

This study revealed a diverse benthic macrofauna for the Moroccan SECS with overall 496 species dominated by Molluscs, Arthropods and Annelids. It represents almost 46\% of the known marine fauna of marine waters of Morocco (1068 taxa, all groups combined) (ONEM, 1998). However, comparison of diversity results between Moroccan SECS may be done with caution since the sampling methods, units and scales are often different, and moreover the diversity of habitats in such ecosystems are high (Chardy and Clavier, 1988; Alongi, 1990).

Patterns in diversity are often related to latitude, a phenomenon known as the latitudinal diversity gradient (LDG), whereby a decrease with increasing latitude is found (Roy et al., 1998; Rex et al., 2000; Attrill et al., 2001; Willig et al., 2003; Hillebrand, 2004). Several hypotheses for the underlying causes for such pattern are suggested, yet none of them is solely sufficiently convincing (Willig et al., 2003; Hillebrand, 2004), although solar energy input (and for the marine territory, the sea surface temperature as its proxy) is most often mentioned as the main acting principle (Rohde, 1992; Roy et al., 1998). Species richness is the most elementary, easy to interpret and widely used measure of biodiversity (e.g. Dornelas et al., 2014). It has been shown to follow a generally unimodal - large-scale $\left(>45^{\circ}\right)$ latitudinal gradient for marine benthic invertebrates with 
306

307

308

309

a peak in equatorial regions (Chaudhary et al., 2016). In contrast to the general LDG pattern, our results showed that species richness and taxonomic diversity indices showed no relationship with latitude. Deviations from the general LDG pattern have also been reported before for European marine benthos by Renaud et al. (2009) who found no or weakly positive relationships. The explanation for this kind of diverting trend is that the impact of local variation in environmental factors is stronger than that of latitude related factors (Gaston, 2000; Renaud et al., 2009). Marine diversity might not follow a strict latitudinal gradient as the drivers of marine diversity themselves are not usually correlated with latitude (Piacenza et al., 2015).

In terms of assemblages composition, the best multivariate model, explaining $33 \%$ of the total variation observed in benthic assemblages, included the type of the SECS (estuaries vs lagoons vs bay), the marine ecoregion (Atlantic vs Mediterranean), the surface of the SECS and the environmental features (minimal temperature, minimal and maximal salinity) as predictors of benthic macrofauna composition in the Moroccan SECS. Such differences in benthic macrofaunal composition across a scale could result from the fact that each ecosystem has its own specific characteristics, which implies an individualistic approach to ecosystem ecology. Indeed, all ecosystems are subject to climatic and environmental forces and it is assumed that their variations induce a response from communities (Möllmann and Diekmann, 2012). The diversity and distribution of organisms can be influenced by the stochastic, ecological and evolutionary processes at local and regional scales (Hubbell, 2001), the limits of dispersion and recruitment of macroinvertebrate taxa (Hurtt \& Pacala, 1995), the structural heterogeneity of the transitional waters (Basset \& Abbiati, 2004) and the consequent selection of macroinvertebrate taxa according to their functional traits and niche needs (MacArthur, 1970).

Variations in species richness and taxonomic composition of benthic macrofauna depends on local oceanographic processes (Aller et al., 2002; Coleman et al., 1997; McCallum et al., 2015), as well as on physiographic characteristics, such as surface area and outlet length (Basset et al., 2006). Variations might be related to ecosystem morphology, substrate type, organic residues (Galeron et al., 2001), salinity (Battaglia, 1959), degree of confinement (Guelorget and Perthuisot, 1983; Guelorget et al., 1983), changes in nutrient concentrations and changes in primary productivity (Galeron et al., 2001). 
According to Spalding et al. (2007), the vast marine region of Morocco can be subdivided into two provinces, the Mediterranean Sea (Alboran Sea Ecoregion) and the Lusitanian (Saharan Upwelling Ecoregion). In corroboration to this subdivision, the type of province (Atlantic vs Mediterranean) was shown to be a significant predictor factor of the composition of the soft-bottom benthic fauna of the Moroccan SECS. Therefore, the currently described marine biogeographic boundaries in Morocco seem to apply to soft-bottom macrofauna of SECS and which environmental drivers were most associated with species differences among these two provinces. Significant differences have been found on the structure of the communities between the marine ecoregions, a fact which may be correlated with the specificities of the ecoregion's physiographical characteristics, as shown by Kong et al. (2013), which emphasizes that the distribution of the macroinvertebrate is correlated with ecoregional characteristics. Moreover, these marine ecoregions are affected by environmental factors (Lara-Lara et al., 2008).

\section{Conclusion}

Our results provide the first broad-scale baseline of composition and diversity patterns of softbottom macrozoobenthos in semi-enclosed coastal systems of Morocco and elucidate the main environmental factors that shape their latitudinal and biogeographic patterns. To our knowledge, the presently reviewed meta-data would be considered as most up-to-dated checklist of the softsediment macrozoobenthos in Moroccan SECS. This checklist is relevant in such poorly known area and fulfills a knowledge gap on SECS in the Northeastern Atlantic and Mediterranean ecoregions. However, the knowledge gained here is insufficient to address perceived shortfalls in knowledge of biodiversity, its importance to ecosystem function, and the threats and consequences of disturbance by anthropogenic activities.

\section{Acknowledgements}

Data for the Tahaddart estuay were obtained in the framework of EU funded WADI Project. Those of the Dakhla bay and the Khnifiss lagoon were partially obtained in the framework of the 
Saharian wetlands of Morocco. The authors are indebted to two anonymous reviewers for their kind and helpful contributions.

\section{Authors' Contributions}

Soilam Boutoumit: Investigation, Data curation, Writing - Original Draft, Visualisation. Reda El Kamcha: Investigation, Data curation, Writing - Original Draft, Visualisation. Oussama Bououarour: Investigation, Data curation, Writing - Original Draft, Visualisation. Latifa Joulami: Investigation, Data curation, Review. Boutahar Loubna: Investigation, Data curation, Review. Abdelaziz Benhousssa: Resources, Funding acquisition. Mohamed Maanan: Review \& Editing, Supervision. Laurent Godet: Writing-Review \& Editing, Validation. Abdellatif Bayed: Resources, Validation. Hocein Bazairi: Conceptualization, Methodology, Writing Original Draft, Review \& Editing, Supervision.

\section{References}

Achab, M., 2011. Les plages et les vasières des environs des embouchures des oueds Tahaddart et Gharifa (NW du Maroc) : dynamique morphosédimentaire et impact des aménagements sur leur évolution récente. Travaux de l'Institut Scientifique, Rabat. 6, 1-12.

Ait Mlik, K., 2009. Contribution à l'étude de l'évolution à long terme des structures benthiques de la lagune de Merja Zerga (Mémoire Master). Université Hassan II. Casablanca, 40pp.

Aksissou, M., 1997. Dynamique des populations d'Orchestia gammarellus (Pallas, 1766) Crustacea, Amphipoda, Talitridae- du littoral méditerranéen du Maroc occidental et impact des aménagements (Thèse Doctorat d'Etat). Université Abdelmalek Essaâdi. Tétouan, 145pp.

Aller, J.Y., Aller, R.C., Green, M.A., 2002. Benthic faunal assemblages and carbon supply along the continental shelf/shelf break-slope off Cape Hatteras, North Carolina. Deep-Sea Res. Pt. II 49 (20), 4599-4625. http://dx.doi.org/10.1016/S0967-0645(02)00131-5

Alongi, D.M., 1990. The ecology of tropical soft-bottom benthic ecosystems. Oceanography and Marine Biology: An Annual Review. 28, 381-496. 
387

388

389

390

391

392

393

394

Anderson, M.J., Gorley, R.N., Clarke, K.R., 2008. PERMANOVA + for PRIMER: guide to software and statistical methods. University of Auckland and PRIMER-E, Plymouth.

Anderson, M.J., Millar, R.B., 2004. Spatial variation and effects of habitat on temperate reef fish assemblages in northeastern New Zealand. J. Exp. Mar. Biol. Ecol. 305, 191-221. https://doi.org/10.1016/j.jembe.2003.12.011

Angel, M.V., 1997. Pelagic diversity in "Marine Biodiversity. Patterns and Processes" (eds R.F.G. Ormond, J.D. Gage \& M.V. Angel). Cambridge University Press, Cambridge, UK, 35-68. . https://doi.org/10.1017/CBO9780511752360

Attrill, M.J., Stafford, R., Rowden, A.A., 2001. Latitudinal diversity patterns in estuarine tidal flats: indications of a global cline. Ecography. 24, 318-324. https://doi.org/10.1034/j.16000587.2001.240309.x

Azirar, A., 2006. Macroafune benthique de l'estuaire d'Oum Rbia (Mémoire DESA). Université Mohammed V. Rabat, 64pp.

Barboza, F.R., Defeo, O., 2015. Global diversity patterns in sandy beach macrofauna: a biogeographic analysis. Sci. Rep. 5, 14515. https://doi.org/10.1038/srep14515

Basset, A., Abbiati, M., 2004. Challenges to transitional water monitoring: ecological descriptors and scales. Aquatic Conservation: Marine and Freshwater Ecosystems. 14, S1-S3. https://doi.org/10.1002/aqc.669

Basset, A., Sabetta, L., Fonnesu, A., Mouillot, D., Do Chi, T., Viaroli, P., Giordani, G., Reizopoulou, S., Abbiati, M., Carrada, G.C., 2006. Typology in Mediterranean transitional waters: new challenges and perspectives. Aquatic Conservation: Marine and Freshwater Ecosystems. 16 (5), 441-455. https://doi.org/10.1002/aqc.767

Battaglia, B., 1959. Final resolution of the symposium on the classification of brackish waters. Archivio Di Oceanografia E Limnologia. 11(suppl), 243-248. 
411

412

413

414

415

416

417

418

419

420

421

422

423

424

425

426

427

428

429

430

431

432

433

Bayed, A., EL Agbani, M.A., Fekhaoui, M., Schouten, J.R., 1988. Benthos of soft substrates in the intertidal zone of the Khnifiss lagoon; in DAKKI M. \& W. LIGNY (eds.): The Khnifiss lagoon and its surrounding environment (Province of Laayoune, Morocco). Trav. Inst. Sci., Mém. Horssérie. 71-80.

Bazaïri, H., 1999. La faune macrobenthique de la lagune de Moulay Bousselham : Structure et successions spatio-temporelles (Thèse Doctorat). Université Mohammed V. Rabat, 199pp.

Bazairi, H., Bayed, A., 2006. L'écosystème benthique de l'estuaire de Tahaddart : biodiversité, fonctionnement et qualité écologique. Unpublished report, WADI Project, 75pp.

Bazairi, H., Gam, M., 2004. Diagnostic pour l'élaboration du plan de gestion: macroinvertébrés estuariens. Projet Gestion Intégrée du Complexe de Zones Humides du Bas Loukkos (Larache, Maroc), Deuxième phase (2004-2005): Actions opérationnels, 40pp.

Bazairi, H., Zourarah, B., 2001. Faune macrobenthique de l'estuaire d'Oum Rbia: biodiversité, distribution spatiale et état de la qualité écologique. Unpublished report, GREPEN, 25pp.

Bazairi, H., Zourarah, B., 2007. Faune macrobenthique de l'estuaire d'Oum Rbia: biodiversité, distribution spatiale et état de la qualité écologique. Unpublished report, GREPEN, 30pp.

Bazairi, H., Zourarah, B., El Kamcha, R., Boutoumit, S., 2017. Faune macrobenthique de l'estuaire d'Oum Rbia: biodiversité, distribution spatiale et état de la qualité écologique. Unpublished report, OMAZINE, 50pp.

Bekkali, R., 1987. Les ostracodes du lac Smir (Maroc nord-occidental) (Thèse Doctorat 3ème cycle). Université Mohammed V de Rabat, 165pp.

Boucher, G., Lambshead, P.J.D., 1995. Ecological biodiversity of marine nematodes in samples from temperate, tropical, and deep sea regions. Conservation Biology, 9, 1594-1604. https://doi.org/10.1046/j.1523-1739.1995.09061594.x 
434

435

436

437

438

439

440

441

442

443

444

445

446

447

448

449

450

451

452

453

454

455

456

457

458

Bououarour, O., 2013. La Macrofaune benthiques des herbiers de Zostera noltii de la lagune de Moulay Bousselham (Merja Zerga) : Structure des communautés et état de la qualité écologique (Mémoire Master). Université Mohammaed V. Rabat, 45pp.

Boussalwa, E., Douira, A., Mokhtar, N., 2000. Contribution à l'étude typologique d'une lagune exposée à la pollution, la lagune de Nador (Maroc): distribution des Crustacés. Cah. Biol. Mar. 41, 255-263.

Boutahar, L., 2014. Evaluation à long terme de la macrofaune benthique dans la lagune de Oualidia (Atlantique, Maroc) entre 2006 et 2014 (Mémoire Master). Université Mohammaed V. Rabat, $105 \mathrm{pp}$.

Chafik, A., Cheggour, M., Cossa, D., Benbrahim, S., Sifeddine, M., 2001. Quality of Moroccan Atlantic coastal waters: water monitoring and mussel watching. Aquat. Living Resour. 14, 239249. https://doi.org/10.1016/S0990-7440(01)01123-8

Chaouti, A., Bayed, A., 2005. Diversité taxonomique et structure de la macrofaune benthique des substrats meubles de la lagune de Smir. In: Bayed A. \& Felicita F. (Eds) - Ecosystèmes côtiers sensibles de la Méditerranée : cas du littoral de Smir. Trav. Inst. Sci. Série générale. 4, 33-42.

Chardy, P., Clavier, J., 1988. Biomass and trophic structure of the macrobenthos in the south-west lagoon of New Caledonia. Marine Biology. 99, 195-202. https://doi.org/10.1007/BF00391981

Chaudhary, C., Saeedi, H., Costello, M.J., 2016. Bimodality of Latitudinal Gradients in Marine Species Richness. Trends in Ecology \& Evolution. 31, 670-676. https://doi.org/10.1016/j.tree.2016.06.001

Chbicheb, A., 1996. Organisation biogéologique d'un bassin paralique : la lagune de Oualidia (côte atlantique marocaine) (Thèse Doctorat 3ème cycle). Université de Nantes, 167pp.

Cheggour, M., 1988. Contribution à l'étude d'un milieu paralique : l'estuaire du Bou Regreg (Côte atlantique marocaine). Condition écologique globale. Etude de la contamination métallique (Thèse de 3ème cycle). ENS. Rabat, 337pp. 
Cherkaoui, S., 2006. Structure et organisation des peuplements macrozoobenthiques de l'estuaire du Bou Regreg après la construction du barrage (Thèse Doctorat). Université Mohammaed V. Rabat, 305 pp.

Clarke, A., 1992. Is there a latitudinal diversity cline in the sea? Trends in Ecology and Evolution. 7, 286-287. https://doi.org/10.1016/0169-5347(92)90222-W.

Clarke, A., Crame, J.A., 1997. Diversity, latitude and time: patterns in the shallow sea. In "Marine Diversity: Patterns and Processes" (eds R.F.G. Ormond, J.D. Gage \& M.V. Angel). Cambridge University Press, Cambridge, UK, 122-147. https://doi.org/10.1017/CBO9780511752360

Clarke, K.R., Gorley, R.N., 2006. PRIMER v.6: User Manual/Tutorial (Plymouth Routines in Multivariate Ecological Research). PRIMER-E, Plymouth.

Clarke, K.R., Warwick, R., 2001. Change in Marine Communities: An approach to statistical analysis and interpretation. PRIMER-E, Plymouth.

Coleman, N., Gason, A.S.H., Poore, C.B., 1997. High species richness in the shallow marine waters of south-east Australia. Mar. Ecol. Prog. Ser. 154, 17-26. http://dx.doi.org/10.3354/meps154017

Crame, J.A., 2000. Evolution of taxonomic diversity gradients in the marine realm: evidence from the composition of recent bivalve faunas. Paleobiology. 26, 188-241. https://doi.org/10.1666/0094-8373(2000)026<0188:EOTDGI >2.0.CO;2

Cruz-Motta, J.J., Miloslavich, P., Guerra-Castro, E., Hernández-Agreda, A., Herrera, C., Klein, E., Barros, F., Navarrete, S.A., Sepúlveda, R., Glasby, T.M., Bigatti, G., Cárdenas-Calle, M., Carneiro, P.B.M., Carranza, A., Flores, A., Gil-Kodaka, P., Gobin, J., Gutiérrez, J., Klein, E., Krull, M., Lazarus, J.F., Londoño-Cruz, E., Lotufo, T., Macaya, E.C., Mora, E., Palomo, G., Parragué, M., Pellizzari, F., Retamales, R., Rocha, R., Romero., 2020. Latitudinal patterns of species diversity on South American rocky shores: Local processes lead to contrasting trends in regional and local species diversity. Journal of Biogeography. 47, 1966-1979. https://doi:10.1111/jbi.13869 
485

486

487

488

489

490

491

492

493

494

495

496

497

498

499

500

501

502

503

504

505

506

507

508

509

510

Cuvelier, J., Riviere, V., Bazairi, H., Benhoussa, A., Cerniaut, C., Charrier, M., Moulis, D., Pupier, P., Qninba, A., 2014. Plan de gestion ; Lagune de Nador - Cordon de la Bocana - partie 1 : Diagnostic socio-économique et écologique. Conservatoire du Littoral. O2TERRE ; AGIR écologique, $177 \mathrm{p}$.

Dornelas, M., Gotelli, N.J., McGill, B., Shimadzu, H., Moyes, F., Sievers, C., Magurran, A.E., 2014. Assemblage time series reveal biodiversity change but not systematic loss. Science. 344, 296-299. https://doi.org/10.1126/science.1248484

El Amraoui, M., Salama, Y., El Amraoui, B., Lazrak, N., Mounkad, M., 2015. Evaluation of the physicochemical and some trace elements of the surface waters of the Moroccan Atlantic estuary: case of the estuary of the river Bouregreg. Carpathian Journal of Earth and Environmental Sciences. 10 (2), 189-198.

El Asri, F., 2019. Composition, organisation et dynamique des communautés zoobenthiques de deux écosystèmes côtiers : la lagune de Oualidia et la Baie de Dakhla (Atlantique Marocain) (Thèse Doctorat). Université Hassan II. Casablanca, 297 pp.

El Asri, F., Zidane, H., Errhif, A., Tamsouri, M.N., Maanan, M., Malouli Idrissi, M., Martin, D., 2017. Polychaete diversity and assemblage structure in the Oualidia Lagoon, Moroccan Atlantic coast. J. Mar. Biol. Assoc. United Kingdom. 98, 1337-1346. https://doi.org/10.1017/S0025315417000388

El Asri, F., Zidane, H., Maanan, M., Tamsouri, M., Errhif, A., 2015. Taxonomic diversity and structure of the molluscan fauna in Oualidia lagoon (Moroccan Atlantic coast). Environmental Monitoring and Assessment. 187, 545. http://dx.doi.org/10.1007/s10661-015-4752-7

El Houssaini, F., 2005. Composition et structure du macrozoobenthos associé à Zostera noltii de la lagune de Smir (Mémoire DESA). Université Hassan II Aïn Chock. Casablanca, 68 pp.

El Kamcha, R., Bououarour, O., Boutoumit, S., Bazairi, H., 2020. Occurrence of the invasive Caprella scaura Templeton, 1836 (Amphipoda: Caprellidae) in the Marchica coastal lagoon (Alboran Sea, Morocco). BioInvasions Records. 9. Article in press. 
Elkaïm, B., 1974. Contribution à l'étude écologique d'un estuaire atlantique marocain : l'estuaire du Bou Regreg (Thèse Doctorat d'Etat). Université de Bordeaux I- 2ème partie, 250 pp.

Ellingsen, K.E., 2002. Soft-sediment benthic biodiversity on the continental shelf in relation to environmental variability. Marine Ecology Progress Series. 232, 15-27. https://doi.org/10.3354/meps232015

Galeron, J., Sibuet, M., Vanreusel, A., Mackenzie, K., Gooday, A., Dinet, A., Wolff, G., 2001. Temporal patterns among meiofauna and macrofauna taxa related to changes in sediment geochemistry at an abyssal NE Atlantic site. Progress in Oceanography. 50 (1-4), 303-324 Sp. Iss. SI). https://doi.org/10.1016/S0079-6611(01)00059-3

Gam, M., de Montaudouin, X., Bazairi, H., 2010. Population dynamics and secondary production of the cockle Cerastoderma edule: A comparison between Merja Zerga (Moroccan Atlantic Coast) and Arcachon Bay (French Atlantic Coast). Journal of Sea Research. 63 (3-4), 191-201. https://doi.org/10.1016/j.seares.2010.01.003

Gaston, K.J., 2000. Global patterns in biodiversity. Nature. 405, 220-227. https://doi.org/10.1038/35012228.

Gauteur, M., 2006. Etablissement du diagnostic écologique d'un environnement lagunaire : la lagune de Oualidia (Côte atlantique, Maroc) (Mémoire Master). Université de Bordeaux 1, 60 pp.

Geawhari, M.A., Huff, L., Mhammdi, N., Trakadas, A., Ammar, A., 2014. Spatial-temporal distribution of salinity and temperature in the Oued Loukkos estuary, Morocco: using vertical salinity gradient for estuary classification. Computational Statistics. 3 (1), 1-9. https://doi.org/10.1186/2193-1801-3-643

Giangrande, A., Licciano, M., 2004. Factors influencing latitudinal pattern of biodiversity: An example using Sabellidae (Annelida, Polychaeta). Biodiversity and Conservation 13, 1633-1646. https://doi.org/10.1023/B:BIOC.0000029327.63397.6b 
Grassle, J.F., Lasserre, P., McIntyre, A.D., Ray, G.C., 1991. Marine Biodiversity and Ecosystem Function: A proposal for an international program of research. Biology International Special Issue. $23,19 \mathrm{p}$.

Guelorget, O., Frisoni, G.F., Perthuisot, J.P., 1983. Zonation biologique des milieux lagunaires: définition d'une échelle de confinement dans le domaine paralique méditerranéen. Journal de Recherche océanographique. 8, 15-35.

Guelorget, O., Perthuisot, J.P., 1983. Le domaine paralique. Expressions géologiques, biologiques et économiques du confinement. Travaux du laboratoire de géologie. 16, 1-136.

Guelorget, O., Perthuisot, J.P., Frisoni, G.F., Monti, D., 1987. Le rôle du confinement dans l'organisation biogéographique de la lagune de Nador (Maroc). OceanolActa. 10 (4), 435-444.

Haddout, S., Maslouhi, A., Magrane, B., Igouzal, M., 2015. Study of salinity variation in the Sebou River Estuary (Morocco). Desalination and Water Treatment. 57 (36), 17075-17086. https://doi.org/10.1080/19443994.2015.1091993

Hawkins, B.A., 2001. Ecology's oldest pattern? Trends Ecol. Evol., 16, 470. https://doi.org/10.1016/S0160-9327(00)01369-7/

Hendrickx, M., Harvey, A.W., 1999. Checklist of anomuran crabs (Crustacea: Decapoda) from the Eastern Tropical Pacific. Belgian Journal of Zoology. 129 (2), 363-389.

Hillebrand, H., 2004. On the generality of the latitudinal diversity gradient. The American Naturalist. 163, 192-211. https://doi.org/10.1086/381004

Hilmi, K., Koutitonsky, V.G., Orbi, A., Lakhdar, J.I., Chagdali, M., 2005. Oualidia lagoon, Morocco: An estuary without a river. African Journal of Aquatic Science. 30 (1), 1-10. https://doi.org/10.2989/16085910509503828

Hubbell, S.P., 2001. The unified neutral theory of biodiversity and biogeography. Princeton University Press, Princeton, 448 pp. 
559

560

561

562

563

564

565

Hurlbert, A.H., Stegen, J.C., 2014. On the processes generating latitudinal richness gradients : identifying diagnostic patterns and predictions. Evol Popul Genet. 5: 420. https://doi.org/10.3389/fgene.2014.00420

Hurtt, G.C., Pacala, S.W., 1995. The consequences of recruitment limitation. Reconciling chance, history and competitive differences between plants. Journal of Theoretical Biology. 176, 1-12. https://doi.org/10.1006/jtbi.1995.0170

Joulami, L., 2013. Interactions entre les conditions écologiques, le benthos et les communautés des limicoles dans un écosystème côtier du Nord-Ouest de L'Afrique (Lagune de Sidi Moussa, Maroc) (Thèse Doctorat.) Université Hassan II. Casablanca, 129 pp.

Kendall, M.A., Aschan, M., 1993. Latitudinal gradients in the structure of macrobenthic communities: a comparison of Arctic, temperate and tropical sites. Journal of Experimental Marine Biology and Ecology. 172, 157-169. https://doi.org/10.1016/0022-0981(93)90095-6

Khalki, A.E., Moncef, M., 2007. Etude du peuplement de copépodes de l'estuaire de l'Oum Er Rbia (côte Atlantique du Maroc): Effets des marées et des lachers de barrages. Lebanese Science Journal. 8 (1), 3-18.

Kinlock, N. L., Prowant, L., Herstoff, E. M., Foley, C. M., Akin-Fajiye, M., Bender, N., Umarani, M., Ryu, H.Y., Şen, B., Gurevitch, J., 2018. Explaining global variation in the latitudinal diversity gradient: Meta-analysis confirms known patterns and uncovers new ones. Global Ecology and Biogeography. 27, 125-141. https://doi.org/10.1111/geb.12665.

Kinlock, N. L., Prowant, L., Herstoff, E. M., Foley, C. M., Akin-Fajiye, M., Bender, N., Umarani, M., Ryu, H.Y., Şen, B., Gurevitch, J., 2019. Open science and meta-analysis allow for rapid advances in ecology: A response to Menegotto et al. (2019). Global Ecology and Biogeography. 28, 1533-1534. https://doi.org/10.1111/geb.12964

Kong, W.J., Meng, W., Zhang, Y., Christopher, G., Qu, X.D., 2013. A freshwater ecoregion delineation approach based on freshwater macroinvertebrate community features and spatial 
584

environmental data in Taizi River Basin, northeastern China. Ecol. Res. 28, 581-592. http://dx.doi.org/10.1007/s11284-013-1048-7

Labrune, C., Grémare, A., Amouroux, J.M., Sardá, R., Gil, J., Taboada, S., 2008. Structure and diversity of shallow soft-bottom benthic macrofauna in the Gulf of Lions (NW Mediterranean). Helgol Mar Res. 62, 201-214. https://doi.org/10.1007/s10152-008-0108-9

Lacoste, M., 1984. Contribution à l'étude écologique de la lagune de Moulay Boussalham (Maroc) (Thèse Doctorat 3ème cycle). Université Paul Sabatier. Toulouse, 207 pp.

Lara-Lara, J., Arreola, J., Calderon, L., Camacho, V., De la Lanza, G., Escofet, A., Espejel, M., Guzman, M., Ladah, L., Lopez, M., Meling, E., Moreno, P., Reyes, H., Rios, E., Zertuche, J., 2008. Los ecosistemas costeros, insulares y epicontinentales. In: Capital natural de México Vol. I : Conocimiento actual de la biodiversidad. Mexico City : CONABIO, 109-134.

Lefrere, L., 2012. Contribution à l'étude de deux lagunes atlantiques marocaines, Khnifiss et Oualidia: faune malacologique, biologie de trois mollusques bivalves et contamination métallique (Thèse Doctorat). Université Ibn Zohr. Agadir, 180 pp.

Maanan, M., Zourarah, B., Carruesco, C., Aajjane, A., Naud, J., 2004. The distribution of heavy metals in the Sidi Moussa lagoon sediments (Atlantic Moroccan Coast). Journal of African Earth Sciences. 39 (3-5), 473-483. https://doi.org/10.1016/j.jafrearsci.2004.07.017

MacArthur, R.H., 1970. Species packing and competitive equilibrium for many species. Theoretical Population Biology. 1, 1-11.

McCallum, A.W., Woolley, S., Błażewicz-Paszkowycz, M., Browne, J., Gerken, S., Kloser, R., Poore, G.C.B., Staples, D., Syme, A., Taylor, J., Walker-Smith, G., Williams, A., Wilson, R.S., 2015. Productivity enhances benthic species richness along an oligotrophic Indian Ocean continental margin. Global Ecol. Biogeogr. 24 (4), 462-471. http://dx.doi.org/10.1111/geb.12255 
607

608

609

610

611

612

613

614

615

616

617

618

619

620

621

622

623

624

625

626

627

628

629

630

Menegotto, A., Kurtz, M.N., Lana, P., 2019. Benthic habitats do show a significant latitudinal diversity gradient: a comment on Kinlock et al. (2018). Global Ecology and Biogeography. 28, 1712-1717. http://doi.org/10.5281/zenodo.3245484

Mergaoui, L., Fekhaoui, M., Bouya, D., Gheit, A., Stambouli, A., 2003. Qualité des eaux et macrofaune benthique d'un milieu estuarien du Maroc ; Cas de l'estuaire de Sebou. Bulletin de 1'Institut Scientifique. 25, 67-75.

Möllmann, C., Diekmann, R., 2012. Marine ecosystem regime shifts induced by climate and overfishing a review for the northern hemisphere. Advances in Ecological Research. 47, 303-347. https://doi.org/10.1016/B978-0-12-398315-2.00004-1

Observatoire National de l'Environnement au Maroc (ONEM)., 1998. Rapport National sur la biodiversité : faune marine, $105 \mathrm{pp}$.

Piacenza, S. E., Barner, A. K., Benkwitt, C. E., Boersma, K. S., Cerny-Chipman, E. B., Ingeman, K. E., Kindinger, T.L., Lee, J.D., Lindsley, A.J., Reimer, J.N., Rowe, J.C., Shen, C., Thompson, K.A., Thurman, L.L., Heppell, S.S., 2015. Patterns and variation in benthic biodiversity in a large marine ecosystem. PLOS One. 10(8): e0135135. https://doi.org/10.1371/journal.pone.0135135

Pierrot-Bults, A.C., 1997. Biological diversity in oceanic macrozooplankton: more than counting species in "Marine Biodiversity: Patterns and Processes" (eds R.F.G. Ormond, J.D. Gage \& M.V. Angel), pp. 69-93. Cambridge University Press, Cambridge, UK. https://doi.org/10.1017/CBO9780511752360

Poore, G.C.B., Wilson, G.D.F., 1993. Marine species richness. Nature. 361, 597-598. https://doi.org/10.1038/361597a0

Pratt, D.R., Pilditch, C.A., Lohrer, A.M., Thrush, S.F., 2014. The effects of short-term increases in turbidity on sandflat microphytobenthic productivity and nutrient fluxes. J. Sea Res. 92, 170177. https://doi.org/10.1016/j.seares.2013.07.009 
631

632

633

634

635

636

637

638

639

640

641

642

643

644

645

646

647

648

649

650

651

652

653

654

655

Qninba, A., Radi, M., Benhoussa, A., Bazairi, H., Menioui, M., 2003. Fiche descriptive sur les zones humides Ramsar (FDR). Catégories approuvées dans la Recommandation 4.7 modifiée par la résolution VIII.13 de la Conférence des Parties contractantes 2005, 9p.

Renaud, P.E., Webb, T.J., Bjørgesæter, A., Karakassis, I., Kędra, M., Kendall, M.A., Labrune, C., Lampadariou, N., Somerfield, P.J., Włodarska-Kowalczuk, M., Vanden Berghe, E., Claus, S., Aleffi, I.F., Amouroux, J.M., Bryne, K.H., Cochrane, S.J., Dahle, S., Degraer, S., Denisenko, G., Deprez, T., Dounas, C., Fleischer, D., Gil J., Grémare, A., Janas, U., Mackie, A.S.Y., Palerud, R., Rumohr, H., Sardá, R., Speybroeck, J., Taboada, S., Van Hoey, G., Węsławski, J.M., Whomersley, P., Zettler, M.L., 2009. Continental-scale patterns in benthic invertebrate diversity: insights from the MacroBen database. Marine Ecology Progress Series. 382, 239-252. https://doi.org/10.3354/meps07963

Rex, M.A., Stuart, C.T., Coyne, G., 2000. Latitudinal gradients of species richness in the deep-sea benthos of the North Atlantic. Proceedings of the National Academy of Sciences of the USA. 97, 4082-4085. https://doi.org/10.1073/pnas.050589497

Rex, M.A., Stuart, C.T., Hessler, R.R., Allen, J.A., Sanders, H.L., Wilson, G.D.F., 1993. Globalscale latitudinal patterns of species diversity in the deep-sea benthos. Nature. 365, 636-639. https://doi.org/10.1038/365636a0

Rohde, K., 1992. Latitudinal gradients in species diversity: the search for the primary cause. Oikos. $65,514-527$.

Roy, K., Jablonski, D., Valentine, J.W., 2000. Dissecting latitudinal diversity gradients: functional groups and clades of marine bivalves. Proceedings of the Royal Society of London B. Biological Sciences. 267, 293-299. https://doi.org/10.1098/rspb.2000.0999

Roy, K., Jablonski, D., Valentine, J.W., Rosenberg, G., 1998. Marine latitudinal diversity gradients: tests of causal hypotheses. Proceedings of the National Academy of Sciences USA. 95, 3699-3702. https://doi.org/10.1073/pnas.95.7.3699 
656

657

658

659

660

661

662

663

664

665

666

667

668

669

670

671

672

673

674

675

676

677

678

679

680

Sanders, H.L., 1968. Marine benthic diversity: a comparative study. Am Nat. 102, 243-282. https://doi.org/10.1086/282541

Semlali, A., Chafik, A., Talbi, M., Budzinski, H., 2012. Origin and Distribution of Polycyclic Aromatic Hydrocarbons in Lagoon Ecosystems of Morocco. The Open Environmental Pollution \& Toxicology Journal. 3, 37-46. https://doi.org/ 10.2174/1876397901203010037

Snelgrove, P.V., 1998. The biodiversity of macrofaunal organisms in marine sediments. Biodiversity and Conservation. 7, 1123-1132. https://doi.org/10.1023/A:1008867313340

Spalding, M.D., Fox, H.E., Allen, G.R., Davidson, N., Ferdaña, Z.A., Finlayson, M., Halpern, B.S., Jorge, M.A., Lombana, A., Lourie, S.A., Martin, K.D., McManus, E., Molnar, J., Recchia, C.A., Robertson, J., 2007. Marine ecoregions of the world: A bioregionalization of coastal and shelf areas. Bioscience. 57, 573-583. https://doi.org/10.1641/B570707

Thorson, G., 1957. Bottom communities. In Treatise on Marine Ecology and Paleoecology. Vol. 1 Ecology (ed. G W Hedgepeth). Memoir of the Geological Society of America. 67, 461-534. https://doi.org/10.1130/MEM67V1

Touhami, F., 2018. Caractérisation des peuplements benthiques des habitats intertidaux de Merja Zerga et leur utilisation par les limicoles hivernants (Thèse Doctorat). Université Mohammed V de Rabat. 219pp.

Touhami, F., Bazairi, H., Badaoui, B., Morabbi, A., Benhoussa, A., 2019. Structure and spatial organization of macrobenthic fauna of intertidal habitats frequented by wintering shorebirds at Merja Zerga lagoon (Moroccan Ramsar Site). Cah. Biol. Mar. 60, 41-50. https:// doi.org/10.21411/CBM.A.26046E89

UN General Assembly, Convention of the Law of the Sea, 10 December., 1982. Available at: https://www.refworld.org/docid/3dd8fd1b4.html (accessed 9 April 2019).

Veiga, P., Torres, A.C., Aneiros, F., Sousa-Pinto, I., Troncoso, J.S., Rubal M., 2016. Consistent patterns of variation in macrobenthic assemblages and environmental variables over multiple 
681 spatial scales using taxonomic and functional approaches. Mar. Environ. Res. 120, 191-201. 682 http://dx.doi.org/10.1016/j.marenvres.2016.08.011

683 Willig, M.R., Kaufman, D.M., Stevens, R.D., 2003. Latitudinal gradients of biodiversity: pattern, 684 process, scale, and synthesis. Annual Review of Ecology, Evolution and Systematics. 34, 273-309. 685 https://doi.org/10.1146/annurev.ecolsys.34.012103.144032

686 WoRMS Editorial Board., 2020. World Register of Marine Species. Available from 687 http://marinespecies.org/ (consulted January 14, 2020).

688 Zidane, H., Mannan, M., Mouradi, A., Maanan, M., El Barjy, M., Zourarah, B., Blais, J.F., 2017. 689 Environmental and ecological risk of heavy metals in the marine sediment from Dakhla Bay, 690 Morocco. Environmental Science and Pollution Research. 24, 7970-7981. 691 https://doi.org/10.1007/s11356-017-8367-0

692 Zine, N.E., 1989. Etude de la malacofaune de la lagune de Nador et dynamique de population de 693 Venerupis decussata (Linné 1767) (Thèse Doctorat 3ème cycle). Université Mohammed V. Rabat, $69497 \mathrm{pp}$.

695 Zine, N.E., 2005. Etude éco-biologique et dynamique des populations de la palourde (Ruditapes 696 decussatus) et analyse typologique de la faune benthique de milieux paraliques atlantico697 méditerranéens du Maroc (Thèse Doctorat d’Etat). Université Moulay Ismail. Meknès, 200 pp. 
Table 1

Environment descriptors of the semi-enclosed coastal systems of Morocco in terms of aquatic system type $(1=$ lagoon; $2=$ estuary; 3 = bay), latitude $(\mathrm{LAT}, \mathrm{N})$, longitude $(\mathrm{LON}, \mathrm{W})$, surface area $\left(\mathrm{km}^{2}\right)$, maximum annual water temperature $\left(\mathrm{M} \mathrm{Temp},{ }^{\circ} \mathrm{C}\right)$, minimum

703 annual water temperature (m Temp, ${ }^{\circ} \mathrm{C}$ ), maximum annual water salinity (M Sal), minimum annual water salinity (m Sal). NA: Nador, SM: Smir, TA: Tahaddart, LO: Loukkos, MB: Moulay Bousselham, SE: Sebou, BR: Bouregreg, OR: Oum Rbia, SI: Sidi Moussa, OU: Oualidia, KH: Khnifiss, DA: Dakhla.

\begin{tabular}{|c|c|c|c|c|c|c|c|c|c|}
\hline System & Type & LAT & LON & Surface Area & M Temp & m Temp & M Sal & m Sal & Reference \\
\hline Nador (NA) & 1 & $35^{\circ} 10^{\prime}$ & $02^{\circ} 51^{\prime}$ & 115 & 28 & 14 & 38 & 32 & El Kamch et al. (2020) \\
\hline Smir (SM) & 1 & $35^{\circ} 42$ & $05^{\circ} 20$ & 0.3 & 32 & 12 & 41 & 7.8 & Chaouti \& Bayed 2005 \\
\hline Tahaddart (TA) & 2 & $35^{\circ} 46^{\prime}$ & $05^{\circ} 42^{\prime}$ & 10 & 26 & 13 & 41 & 21 & Achab 2011 \\
\hline Loukkos (LO) & 2 & $35^{\circ} 07^{\prime}$ & $06^{\circ} 00^{\prime}$ & 72 & 27 & 15 & 34 & 22 & Geawhari et al., 2014 \\
\hline Moulay Bousselham (MB) & 1 & $34^{\circ} 51^{\prime}$ & $06^{\circ} 16^{\prime}$ & 27 & 28 & 11 & 35 & 27 & Gam et al., 2010 \\
\hline Sebou (SE) & 2 & $34^{\circ} 16^{\prime}$ & $06^{\circ} 39^{\prime}$ & 17.5 & 30 & 16 & 35 & 12 & Haddout et al., 2015 \\
\hline Bouregreg (BR) & 2 & $34^{\circ}$ & $06^{\circ} 50^{\prime}$ & 4000 & 45 & 14 & 30 & 10 & Cherkaoui 2006; El Amraoui et al., 2015 \\
\hline Oum Rbia (OR) & 2 & $33^{\circ} 28^{\prime}$ & $08^{\circ} 34^{\prime}$ & 1.5 & 25 & 15 & 35 & 30 & Khalki \& Moncef 2007 \\
\hline Sidi Moussa (SI) & 1 & $32^{\circ} 54^{\prime}$ & $08^{\circ} 49^{\prime}$ & 4.2 & 27 & 15 & 33 & 22 & Maanan et al., 2004 \\
\hline Oualidia (OU) & 1 & $32^{\circ} 45^{\prime}$ & $08^{\circ} 30^{\prime}$ & 3.0 & 21 & 16 & 36 & 28 & Hilmi et al., 2005 \\
\hline Khnifiss (KH) & 1 & $28^{\circ} 03^{\prime}$ & $12^{\circ} 15^{\prime}$ & 65 & 22 & 16 & 38 & 34 & Semlali et al., 2012 \\
\hline Dakhla (DA) & 3 & $23^{\circ} 45^{\prime}$ & $15^{\circ} 50^{\prime}$ & 400 & 26 & 14 & 40 & 37 & Zidane et al., 2018 \\
\hline
\end{tabular}


Table 2

709 Species richness (S) and taxonomic distinctness indices values in the semi-enclosed coastal

710 ecosystems of Morocco. $\Delta^{+}$: taxonomic distinctness, $\mathrm{S} \Delta^{+}$: total taxonomic distinctness, $\Phi^{+}$:

711 average phylogenetic diversity, $\Lambda^{+}$: variation in taxonomic distinctness, $\mathrm{S} \Phi^{+}$: total phylogenetic

712 diversity. NA: Nador, SM: Smir, TA: Tahaddart, LO: Loukkos, MB: Moulay Bousselham, SE:

713 Sebou, BR: Bouregreg, OR: Oum Rbia, SI: Sidi Moussa, OU: Oualidia, KH: Khnifiss, DA:

714 Dakhla.

\begin{tabular}{lcllllll}
\hline Sites & Sampling effort & $\mathbf{S}$ & $\boldsymbol{\Delta}^{+}$ & $\mathbf{S} \boldsymbol{\Delta}^{+}$ & $\boldsymbol{\Lambda}^{+}$ & $\boldsymbol{\Phi}^{+}$ & $\mathbf{S \Phi}^{+}$ \\
\hline NA & 366 & 158 & 90 & 14232 & 279.9 & 47.7 & 7533.3 \\
SM & 123 & 53 & 89.6 & 4748.1 & 293.3 & 56.3 & 2983.3 \\
TA & 99 & 40 & 88.7 & 3549.6 & 311.6 & 55.0 & 2200.0 \\
LO & 134 & 32 & 89.1 & 2852.7 & 300.5 & 60.4 & 1933.3 \\
MB & 599 & 161 & 90.5 & 14569.2 & 268.7 & 47.8 & 7700.0 \\
SE & 7 & 94 & 87.8 & 8162.0 & 275.5 & 52.9 & 4916.7 \\
BR & 120 & 101 & 89.9 & 9075.7 & 278.3 & 51.7 & 5216.7 \\
OR & 39 & 48 & 88.5 & 4247.5 & 328.8 & 51.4 & 2466.7 \\
SI & 117 & 57 & 90.2 & 5141.7 & 271.3 & 56.4 & 3216.7 \\
OU & 43 & 105 & 89.8 & 9428.2 & 268.2 & 48.6 & 5100.0 \\
KH & 29 & 62 & 88.6 & 5491.8 & 333.7 & 51.9 & 3216.7 \\
DA & 100 & 105 & 89.7 & 9414.4 & 255.7 & 50.6 & 5316.7 \\
\hline
\end{tabular}

715

716

717

718 
720 Table 3. Results of PERMANOVAs testing for the effect of the type of ecosystem (Lagoon -

721 Estuary) on species richness and taxonomic.

\begin{tabular}{|c|c|c|c|c|c|c|c|c|}
\hline Source & $d f$ & MS & Pseudo-F & $\mathbf{P}($ perm $)$ & $d f$ & MS & Pseudo-F & $P($ perm) \\
\hline & \multicolumn{4}{|c|}{ Species richness (S) } & \multicolumn{4}{|c|}{ Taxonomic distinctness ( $(+)$} \\
\hline Type & 1 & 312,26 & 1,9692 & 0,1845 & 1 & 0,20702 & 5,188 & 0,0528 \\
\hline Residual & 9 & 158,57 & & & 9 & $3,99 \mathrm{E}-02$ & & \\
\hline \multirow[t]{2}{*}{ Total } & 10 & & & & 10 & & & \\
\hline & \multicolumn{4}{|c|}{ Total taxonomic distinctness $(\mathrm{S} \Delta+)$} & \multicolumn{4}{|c|}{ Variation in taxonomic distinctness $\left(\Lambda^{+}\right)$} \\
\hline Type & 1 & 330,52 & 2,076 & 0,1825 & 1 & 3,5385 & 0,87669 & 0,3505 \\
\hline Residual & 9 & 159,21 & & & 9 & 4,0363 & & \\
\hline \multirow[t]{2}{*}{ Total } & 10 & & & & 10 & & & \\
\hline & \multicolumn{4}{|c|}{ Average phylogenetic diversity $(\Phi+)$} & \multicolumn{4}{|c|}{ Total phylogenetic diversity $\left(S \Phi^{+}\right)$} \\
\hline Type & 1 & 5,0236 & 1,4911 & 0,2565 & & 251,47 & 2,0287 & 0,1876 \\
\hline Residual & 9 & 3,3689 & & & 9 & 123,95 & & \\
\hline Total & 10 & & & & 10 & & & \\
\hline
\end{tabular}




\begin{tabular}{|c|c|c|c|c|c|c|c|c|c|c|c|c|}
\hline & \multicolumn{2}{|c|}{ Mediterranean } & \multicolumn{10}{|c|}{ Atlantic } \\
\hline & NA & SM & TA & LO & MB & $\begin{array}{l}\mathbf{S E} \\
\end{array}$ & BO & $\mathbf{O R}$ & SI & $\mathbf{O U}$ & KH & DA \\
\hline 1974 & & & & & & & 1, IS & & & & & \\
\hline 1984 & & & & & $2, I$ & & & & & & & \\
\hline 1987 & $4, \mathrm{~S}, \mathrm{~B}$ & $3, \mathrm{~S}$ & & & & & 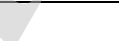 & & & & & \\
\hline 1988 & & & & & & 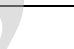 & $6, I$ & & & & $5, \mathrm{I}$ & \\
\hline 1989 & $7, \mathrm{~S}$ & & & & 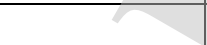 & 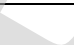 & & & & & & \\
\hline 1995 & & & & & & & & & & & & \\
\hline 1996 & & & & & 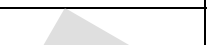 & & & & & $8, I$ & & \\
\hline 1997 & & $9, \mathrm{I}$ & & & 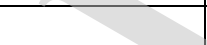 & & & & & & & \\
\hline 1999 & & & & & 10, IS & & & & & & & \\
\hline 2000 & $11, \mathrm{~S}$ & & & & $\mathrm{~T}$ & & & & & & & \\
\hline 2001 & & & & & -7 & & & 12, IS, B & & & & \\
\hline 2003 & & & & & 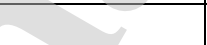 & $13, \mathrm{~S}$ & & & & & & \\
\hline 2004 & & & & $14, \mathrm{IS}, \mathrm{B}$ & $\gamma$ & & & & & & & \\
\hline 2005 & & \begin{tabular}{l|l}
$15, \mathrm{I}$ & $16, \mathrm{I}$
\end{tabular} & & P & ter & 17, IS & & & & & & \\
\hline 2006 & & & 19, IS & 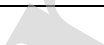 & & & 20 , IS & & & 21, IS & & \\
\hline 2007 & & & & 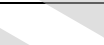 & $y$ & & & $22, \mathrm{IS}, \mathrm{B}$ & & & & \\
\hline 2009 & & & & $\frac{1}{4}$ & 23 , IS & & & & & & & \\
\hline 2012 & & & 2 & r & & & & & & & 24, I & \\
\hline 2013 & & & $\bar{z}$ & 3 & $25, I$ & & & & 26, I, B & & & \\
\hline 2014 & $28, S$ & & - & & & & & & & 27, IS & & \\
\hline 2015 & & 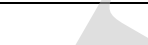 & 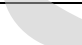 & & & & & & & 29, IS & & \\
\hline 2016 & & $7 \quad y$ & 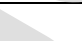 & & & & & & & & & \\
\hline 2017 & & & se & & & & & 30, IS, B & & 31, IS & & \\
\hline 2018 & & & $\checkmark$ & & $32, \mathrm{I}, \mathrm{B}$ & & & & & & & \\
\hline 2019 & & & & & & & & & & 33, IS & & 33, IS \\
\hline 2020 & $36, \mathrm{~S}, \mathrm{~B}$ & & & $34, \mathrm{I}, \mathrm{B}$ & \begin{tabular}{l|l|}
34, I, B & 35, IS, B
\end{tabular} & & & & $34, \mathrm{I}, \mathrm{B}$ & $34, \mathrm{I}, \mathrm{B}$ & $34, \mathrm{I}, \mathrm{B}$ & $34, \mathrm{I}, \mathrm{B}$ \\
\hline
\end{tabular}

\section{Table 4}

Gaps and knowledge gained from studies performed on soft-bottom zoomacrobenthos of the Moroccan SECS. NA: Nador. SM: Smir. TA: Tahaddart. LO: Loukkos. MB: Moulay Bousselham. SE: Sebou. BR: Bouregreg. OR: Oum Rbia. SI: Sidi Moussa. OU: Oualidia. KH: Khnifiss. DA: Dakhla. $\mathbf{I}=$ Intertidal $\mathbf{S}=$ Subtidal. $\mathbf{B}=$ Biomass. References (Numbers 1-36): (1) Elkaïm (1974); (2) Lacoste (1984); (3) Bekkali (1987); (4) Guelorget et al. (1987); (5) Bayed et al. (1988); (6) Cheggour (1988); (7) Zine (1989); (8) Chbicheb (1996); (9) Aksissou (1997); (10) Bazairi (1999); (11) Boussalwa et al. (2000); (12) Bazairi \& Zourarah (2001); (13) Mergaoui et al. (2003); (14) Bazairi \& Gam (2004); (15) Chaouti \& Bayed (2005); (16) El Houssaini (2005); (17) Zine (2005); (18) Azirar (2006); (19) Bazairi \& Bayed (2006); (20) Cherkaoui (2006); (21) Gauteur (2006); (22) Bazairi \& Zourarah (2007); (23) Ait Mlik (2009); (24) Lefrere (2012); (25) Bououarour (2013); (26) Joulami (2013); (27) Boutahar (2014); (28) Cuvelier et al. (2014); (29) El Asri et al. (2015); (30) Bazairi et al. (2017); (31) El Asri et al. (2017); (32) Touhami (2018); (33) El Asri (2019); (34) Bououarour (unpublished data); (35) Boutoumit (unpublished data); (36) El Kamcha (unpublished data). Grey colour indicates studies that can be considered as references for respective sites. 


\section{Figure Captions:}

Figure 1. Map showing the geographical position of the semi-enclosed coastal systems of Morocco considered in this study. $\star$ : lagoon; $\boldsymbol{\Lambda}$ : estuary; $\mathbf{\square}$ : bay.

Figure 2. Species richness by biogeographical repartition in the semi-enclosed coastal systems of Morocco. A: Atlantic. AM: Atlantico-Mediterranean. and M: Mediterranean. NA: Nador. SM: Smir. TA: Tahaddart. LO: Loukkos. MB: Moulay Bousselham. SE: Sebou. BR: Bouregreg. OR: Oum Rbia. SI: Sidi Moussa. OU: Oualidia. KH: Khnifiss. DA: Dakhla.

Figure 3. Confidence funnel (mean and $95 \%$ confidence interval) of the variation in taxonomic distinctness (A) and taxonomic distinctness (B) in the Moroccan Semi-enclosed coastal systems. NA: Nador. SM: Smir. TA: Tahaddart. LO: Loukkos. MB: Moulay Bousselham. SE: Sebou. BR: Bouregreg. OR: Oum Rbia. SI: Sidi Moussa. OU: Oualidia. KH: Khnifiss. DA: Dakhla.

Figure 4. Dendrogram of cluster analysis using group-average linkage of Bray-Curtis similarities based on benthic macrofauna composition in the semi-enclosed coastal systems of Morocco. NA: Nador. SM: Smir. TA: Tahaddart. LO: Loukkos. MB: Moulay Bousselham. SE: Sebou. BR: Bouregreg. OR: Oum Rbia. SI: Sidi Moussa. OU: Oualidia. KH: Khnifiss. DA: Dakhla.

Figure 5. Ordination of the semi-enclosed coastal systems using the Principal coordinates ordination (PCO) with vectors (longer than 0.7 ) and clusters overlay. NA: Nador. SM: Smir. TA: Tahaddart. LO: Loukkos. MB: Moulay Bousselham. SE: Sebou. BR: Bouregreg. OR: Oum Rbia. SI: Sidi Moussa. OU: Oualidia. KH: Khnifiss. DA: Dakhla.

Figure 6. Distance-based redundancy analysis plot and the correlated variables that explained the semi-enclosed coastal systems distribution based on benthic macrofauna composition. NA: Nador. SM: Smir. TA: Tahaddart. LO: Loukkos. MB: Moulay Bousselham. SE: Sebou. BR: Bouregreg. OR: Oum Rbia. SI: Sidi Moussa. OU: Oualidia. KH: Khnifiss. DA: Dakhla. 
Figure 1

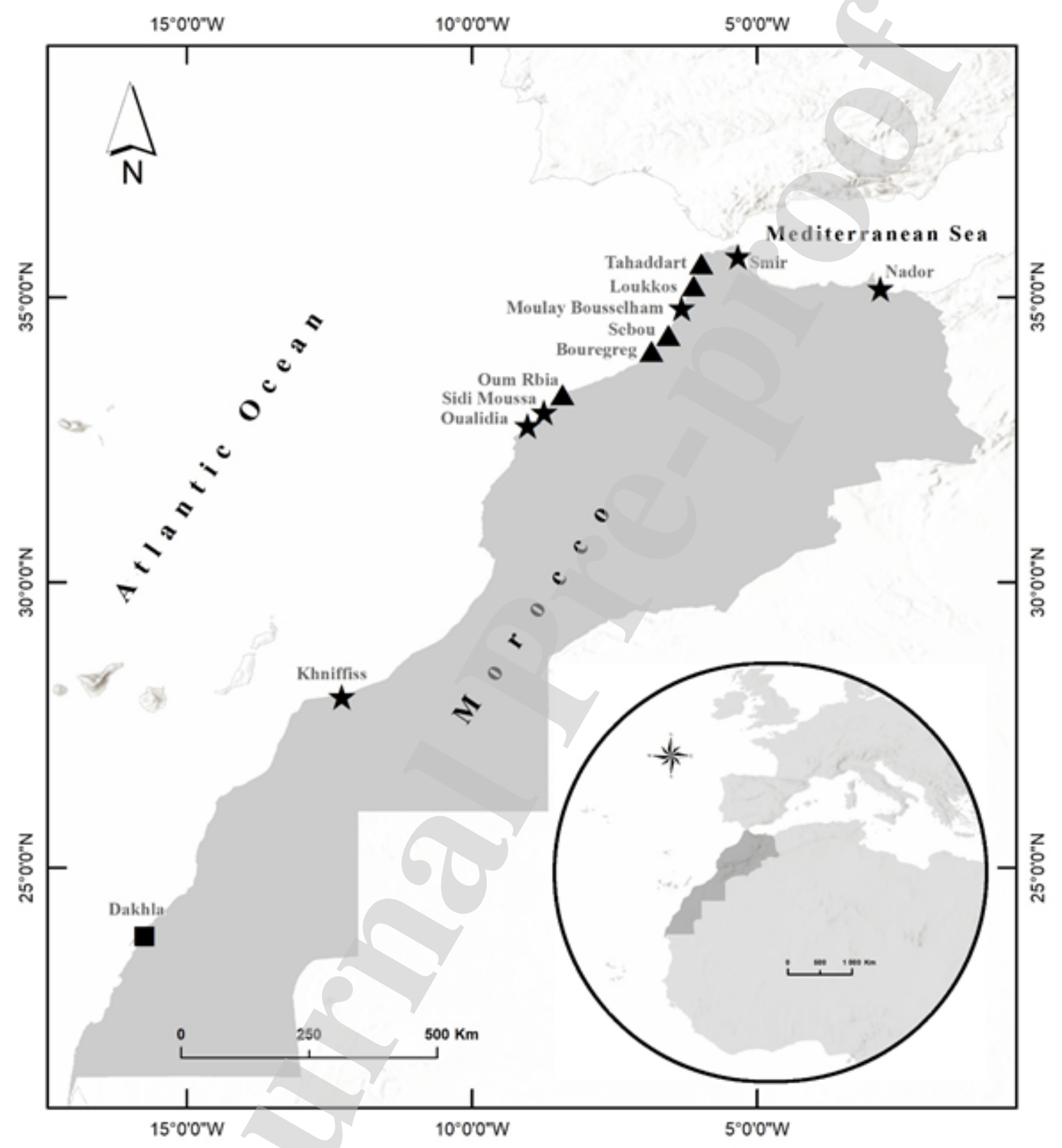


Figure 2

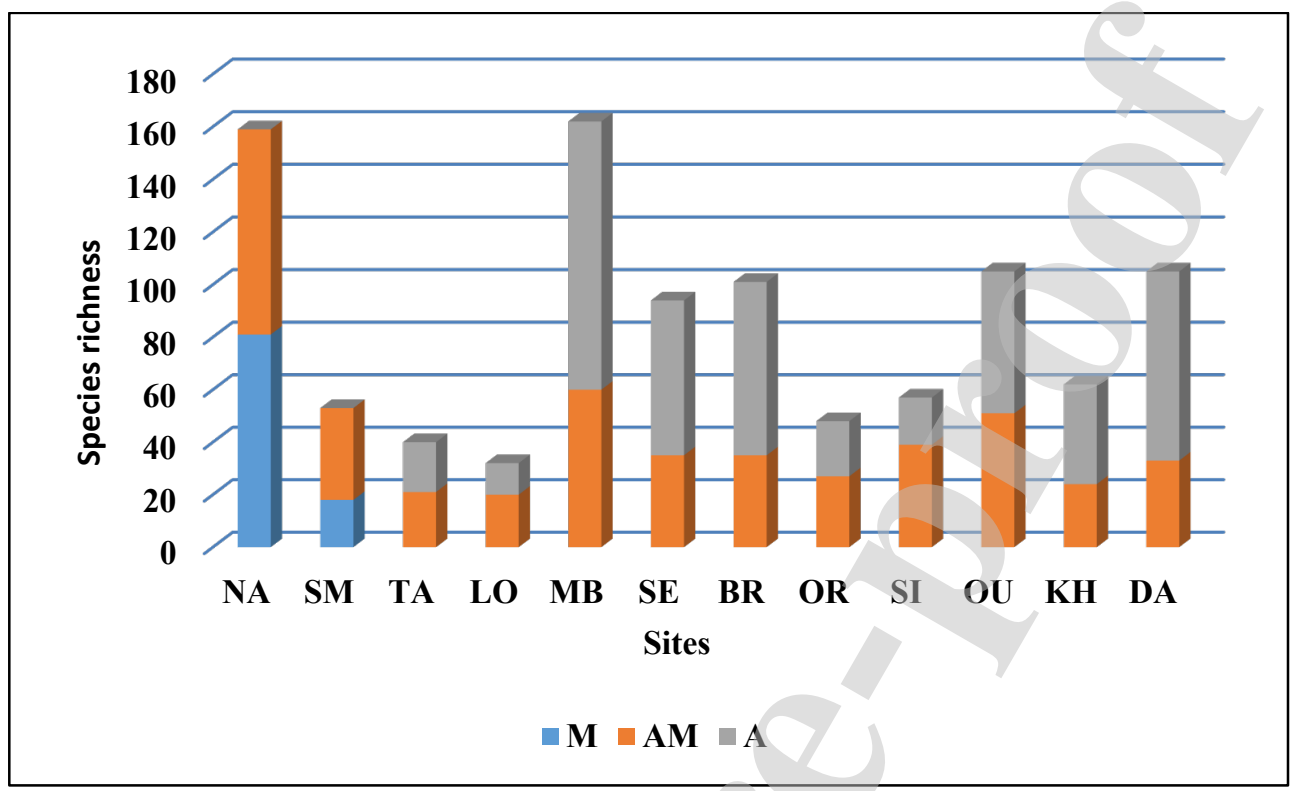


$785 \quad$ Figure 3
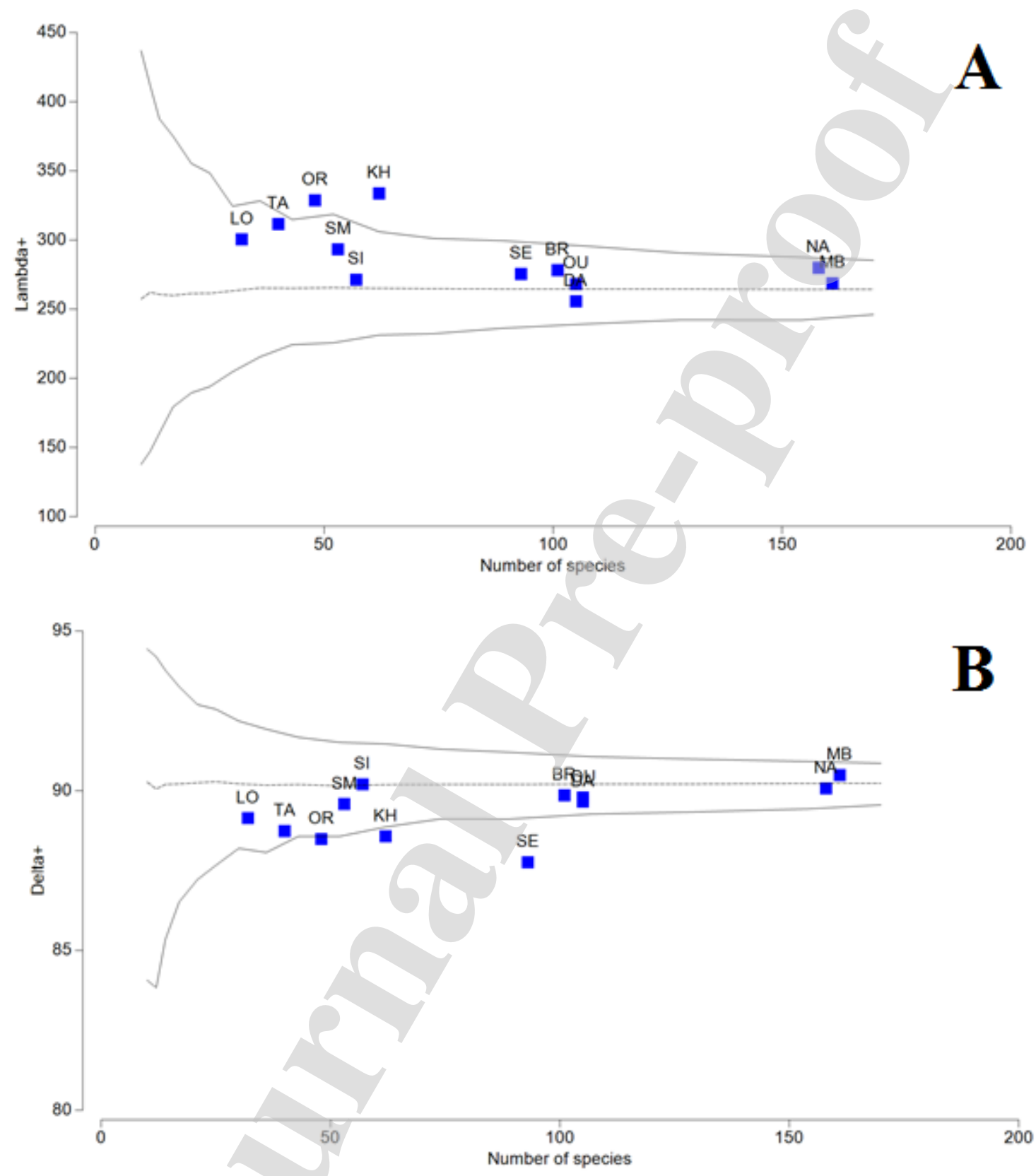

786

787 
$790 \quad$ Figure 4

791

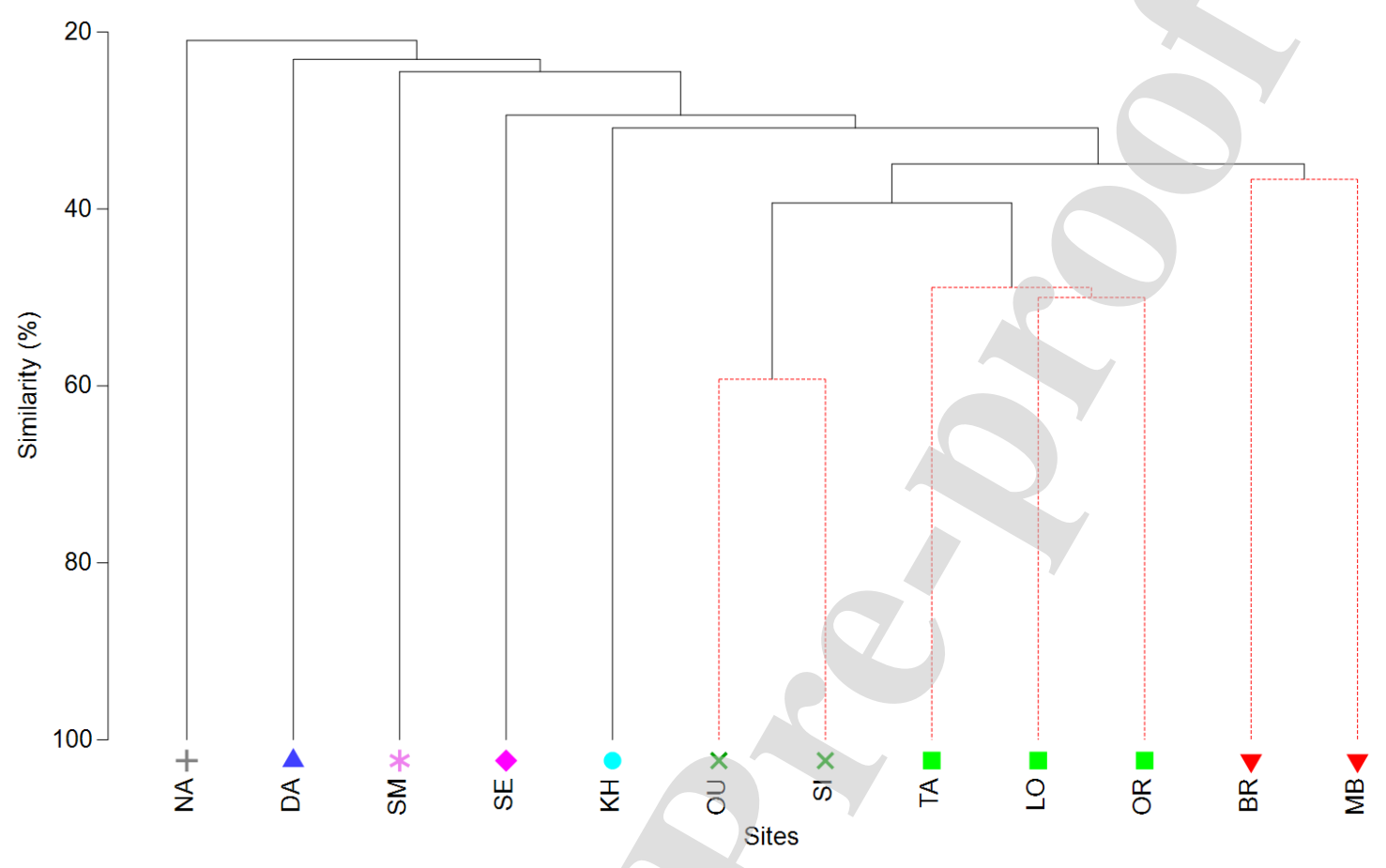

793

794

795

796

797

798

799

800 
801

802

803

804

805

806

807

808

809

810

811

812

813

\section{Figure 5}

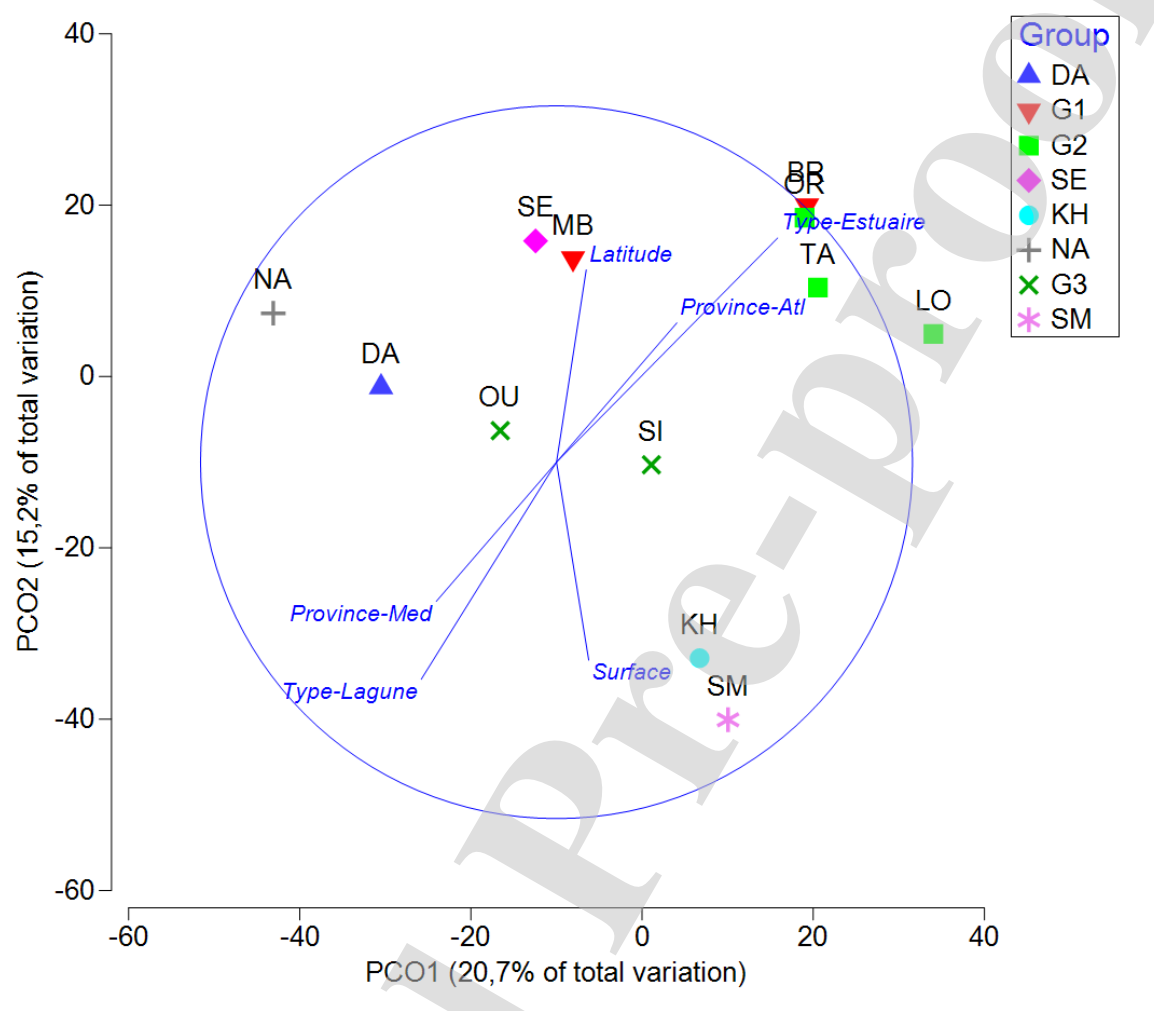




\section{$814 \quad$ Figure 6}

815
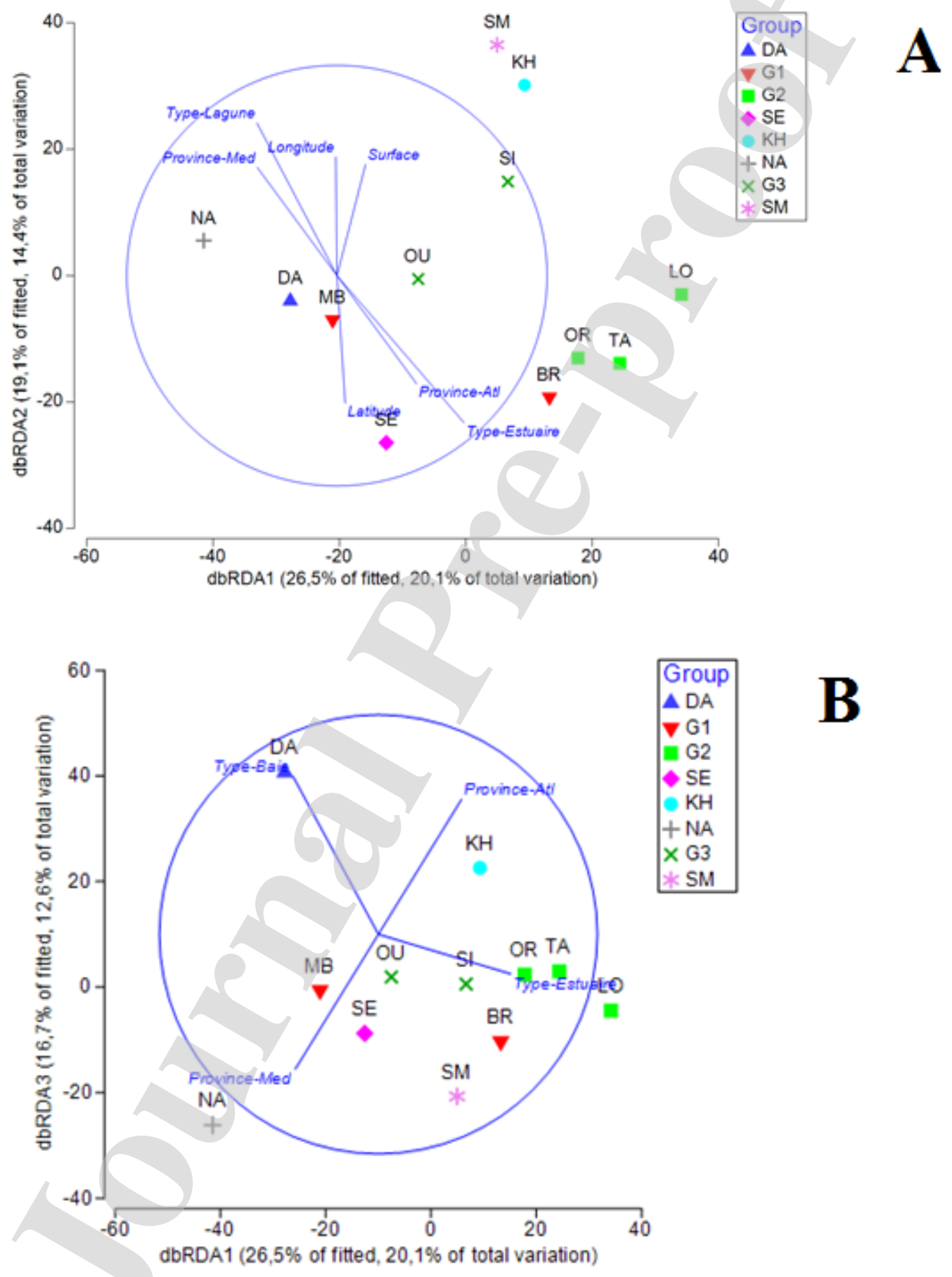

B 
- The first broad-scale baseline of soft-bottom macrozoobenthos in semi-enclosed coastal systems (SECS) of Morocco is presented

- 496 species were recorded from the Moroccan SECS and belong to 7 phyla, 21 classes, 65 orders and 201 families

- Species richness and taxonomic diversity indices showed no relationship with SECS features including latitude

- The type of the SECS (estuaries vs lagoons vs bay), the marine ecoregion (Atlantic vs Mediterranean), the surface of the SECS and the environmental features (minimal temperature, minimal and maximal salinity) are the most predictors of benthic macrofauna composition in the Moroccan SECS 


\section{Author statement file:}

Soilam Boutoumit: Investigation, Data curation, Writing - Original Draft, Visualisation. Reda El Kamcha: Investigation, Data curation, Writing - Original Draft, Visualisation. Oussama Bououarour: Investigation, Data curation, Writing - Original Draft, Visualisation. Latifa Joulami: Investigation, Data curation, Review. Boutahar Loubna: Investigation, Data curation, Review.

Abdelaziz Benhousssa: Resources, Funding acquisition. Mohamed Maanan: Review \& Editing, Supervision. Laurent Godet: Writing-Review \& Editing, Validation. Abdellatif Bayed: Resources, Validation. Hocein Bazairi: Conceptualization, Methodology, Writing - Original Draft, Review \& Editing, Supervision. 


\section{Declaration of interests}

The authors (Soilam Boutoumit, Reda El Kamcha, Oussama Bououraour, Latifa Joulami, Loubna Boutahar, Abdelaziz Benhoussa, Mohamed Maanan, Laurent Godet, Abdellatif Bayed and Hocein Bazairi) declare that they have no known competing financial interests or personal relationships that could have appeared to influence the work reported in the paper entitled "Soft-bottom macrozoobenthos in semi-enclosed coastal systems of Morocco"

In behalf of all authors: Hocein Bazairi

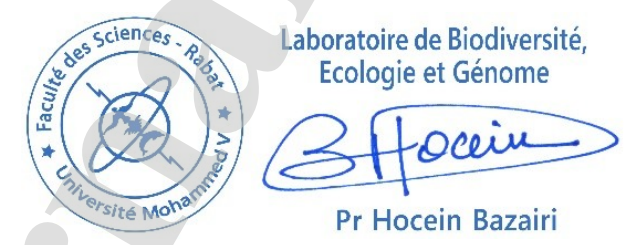

